\title{
PENNSTATE
}

800

1855

Feasibility Analysis for Installing a Circulating Fluidized Bed Boiler for Cofiring Multiple Biofuels and Other Wastes with Coal at Penn State University

First Quarterly Technical Progress Report for the Period 06/15/2000 to 09/14/2000

By

Bruce G. Miller and Curtis Jawdy

The Energy Institute

October 9, 2000

Work Performed Under Grant No. DE-FG26-00NT40809--01

For

U.S. Department of Energy

National Energy Technology Laboratory

P.O. Box 10940

Pittsburgh, Pennsylvania 15236

By

The Energy Institute

The Pennsylvania State University

C211 Coal Utilization Laboratory

University Park, Pennsylvania 16802 


\section{Feasibility Analysis for Installing a Circulating Fluidized Bed Boiler for Cofiring Multiple Biofuels and Other Wastes with Coal at Penn State University}

First Quarterly Technical Progress Report for the Period 06/15/2000 to 09/14/2000

By

Bruce G. Miller and Curtis Jawdy

The Energy Institute

October 9, 2000

Work Performed Under Grant No. DE-FG26-00NT40809

For

U.S. Department of Energy

National Energy Technology Laboratory

P.O. Box 10940

Pittsburgh, Pennsylvania 15236

By

The Energy Institute

The Pennsylvania State University

C211 Coal Utilization Laboratory

University Park, Pennsylvania 16802 


\section{DISCLAIMER}

This report was prepared as an account of work sponsored by an agency of the United States Government. Neither the United States Government nor any agency thereof, nor any of their employees, makes any warranty, express or implied, or assumes any legal liability or responsibility for the accuracy, completeness, or usefulness of any information, apparatus, product, or process disclosed, or represents that its use would not infringe privately owned rights. Reference herein to any specific commercial product, process, or service by trade name, trademark, manufacturer, or otherwise does not necessarily constitute or imply its endorsement, recommendation, or favoring by the United States Government or any agency thereof. The views and opinions of authors expressed herein do not necessarily state or reflect those of the United States Government or any agency thereof. 


\section{EXECUTIVE SUMMARY}

The Pennsylvania State University, under contract to the U.S. Department of Energy, National Energy Technology Laboratory is performing a feasibility analysis on installing a state-of-the-art circulating fluidized bed boiler and ceramic filter emission control device at Penn State's University Park campus for cofiring multiple biofuels and other wastes with coal or coal refuse, and developing a test program to evaluate cofiring multiple biofuels and coal-based feedstocks.

The objective of the project is being accomplished using a team that includes personnel from Penn State's Energy Institute and the Office of Physical Plant, Foster Wheeler Energy Corporation, Foster Wheeler Development Corporation, and Cofiring Alternatives.

The major emphasis of work during this reporting period was to assess the types and quantities of potential feedstocks and collect samples of them for analysis.

Approximately twenty different biomass, animal waste, and other wastes were collected and analyzed. 


\section{TABLE OF CONTENTS}

$\underline{\text { Page }}$

LIST OF FIGURES .............................................................................

LIST OF TABLES ............................................................................... vi

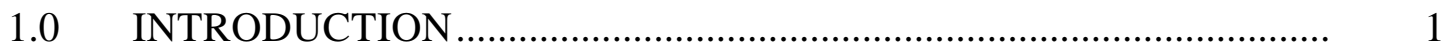

1.1 Penn State's Steam Plants ........................................................ 2

1.2 Project Outline................................................................... 3

2.0 TASK 1. INFORMATION AND SAMPLE COLLECTION................ 8

3.0 TASK 2. BIOFUELS AND BIOFUEL/COAL CHARACTERIZATION .................................................. 8

4.0 TASK 3. DEVELOP CONCEPTUAL DESIGN ............................... 16

5.0 TASK 4. DEVELOP PRELIMINARY TEST PROGRAM/BUDGET .. 16

6.0 TASK 5. DETERMINE SYSTEM/PROGRAM ECONOMICS .......... 16

7.0 TASK 6. COMPLETE FEASIBILITY STUDY .................................. 16

8.0 TASK 7. PROJECT MANAGEMENT/REPORTING ......................... 16

9.0 MISCELLANEOUS ACTIVITIES .................................................... 16

10.0 NEXT QUARTERLY ACTIVITIES..................................................... 17

11.0 ACKNOWLEDGMENTS ......................................................... 17

APPENDIX A. ANALYSIS AND PHOTOGRAPHS OF

POTENTIAL FEEDSTOCKS ............................................ 18 


\section{LIST OF FIGURES}

Page

FIGURE 1. Penn State's West Campus and East Campus Steam Plants....... 4

FIGURE 2. Milestone Schedule.............................................................. 6

FIGURE 3. Photograph of Sewage Sludge Sample .................................... 11

FIGURE 4. Photograph of Dairy Tie-Stall Manure .................................. 12

FIGURE 5. Photograph of Sheep Manure ................................................ 13

FIGURE 6. Photograph of Manure from the Covered Manure Barn ............ 14

FIGURE 7. Photograph of Red Oak Shavings........................................... 15 


\section{LIST OF TABLES}

$\underline{\text { Page }}$

TABLE 1. Description of Milestones .................................................... 7

TABLE 2. Waste and By-Product Streams that were Produced at the University Park Campus during 1998....................................... 9

TABLE 3. Potential CFB Feedstocks .................................................... 10 


\subsection{Introduction}

The Pennsylvania State University, under contract to the U.S. Department of Energy (DOE), National Energy Technology Laboratory (NETL) is performing a feasibility analysis on installing a state-of-the-art circulating fluidized bed (CFB) boiler and ceramic filter emission control device at Penn State's University Park campus for cofiring multiple biofuels and other wastes with coal or coal refuse, and developing a test program to evaluate cofiring multiple biofuels and coal-based feedstocks. Penn State currently operates an aging stoker-fired steam plant at its University Park campus and has spent considerable resources over the last ten to fifteen years investigating boiler replacements and performing life extension studies. This effort, in combination with a variety of agricultural and other wastes generated at the agricultural-based university and the surrounding rural community, has led Penn State to assemble a team of fluidized bed and cofiring experts to assess the feasibility of installing a CFB boiler for cofiring biomass and other wastes along with coalbased fuels.

The objective of the project is being accomplished using a team that includes personnel from Penn State's Energy Institute and the Office of Physical Plant, Foster Wheeler Energy Corporation, Foster Wheeler Development Corporation, and Cofiring Alternatives.

The CFB boiler system that will be considered in the feasibility analysis is unique in that it will:

1) be of compact versus traditional design;

2) include modules to evaluate ceramic filters, along with fabric filters, for particulate matter control (recent work at Penn State has shown that ceramic filters have potential advantages regarding fine particulate matter and trace elements, i.e., mercury, removal);

3) contain an advanced instrumentation package including temperature and pressure sensors, deposition and slagging probes, heat flux meters, and corrosion/ erosion panels;

4) contain multi-fuel capabilities (making it a versatile test site for industry and government studies); and

5) be a commercial facility in a rural, agricultural setting that contains an engineering and agricultural-based university.

The state-of-the-art CFB boiler and ceramic filter device would allow the University the opportunity to do the following:

- to more economically supply heat to the University Park Campus;

- to reduce the amount of air-borne pollutants $\left(\mathrm{NO}_{\mathrm{x}}, \mathrm{SO}_{2}\right.$, particulate matter, and potentially trace elements), thus helping to reduce the overall emissions from the University's central heating plant;

- to reduce the amount of agricultural and other waste products produced by the University that must be disposed; 
- to help reduce the amount of $\mathrm{CO}_{2}$ (a greenhouse gas) emissions by combusting waste biofuels; and

- to ultimately serve as a large-scale (commercial demonstration size) test facility for federally and other outside source-funded research and development projects related to cofiring of biofuels with coal and other coal refuse.

It is the intent of the feasibility analysis to assess: the economics of producing steam; the economics of off-sets such as utilizing multiple biomass and other wastes (i.e., sewage sludge); the value of a unique CFB test facility to perform research for industry, such as Foster Wheeler, and government agencies, such as the DOE; the environmental aspects of the CFB boiler; and the availability of funding from multiple sources including University, state, and federal sources. The feasibility study will also include developing a multiple-year program to test biofuels as the boiler system will be unique in that it will be heavily instrumented and will be able to handle multiple fuels.

\subsection{Penn State's Steam Plants}

Penn State University, Office of Physical Plant (OPP) currently operates a coalfired central steam plant at the University Park Campus. The installed coal-fired capacity is $450,000 \mathrm{lb} / \mathrm{h}$ (pph) steam generated by four vibra-grate stoker boilers at $250 \mathrm{psig} / 540^{\circ} \mathrm{F}$, which are used as baseload units. Additional steam generating capacity is available with gas or oil fire in three other boilers, totaling 260,000 pph. Electricity is also produced, as a byproduct, with a maximum installed generating capacity of $6,500 \mathrm{~kW}$. Currently, at peak operation, which occurs when classes are in session and winter conditions experienced, $420,000 \mathrm{pph}$ of steam are required. Steam requirements during the summer are 125,000 pph while approximately 200,000 pph of steam is required during the spring/fall.

Although the present total steam generating capacity is $710,000 \mathrm{pph}$, the University prefers not to operate the gas and oil-fired boilers because the price of the natural gas and fuel oil is significantly higher than that of the coal. Ideally, the University would like to fire only coal and have sufficient coal firing capability to allow for one coal-fired boiler to be down without impacting steam production or forcing the operation of a gas/oil-fired boiler.

The four stoker-fired boilers at Penn State are all between 32 and 39 years old. When the units were installed (1961 to 1968), the projected life of a typical unit was expected to be approximately 40 years. Since that time, the life of the steam generating units has been reevaluated based on changing technology, economic, and regulatory factors. Life extension studies on many plants have now indicated that economic lives up to 50 to 60 years may be possible depending on the levels of maintenance, type of operation of the units, the cost of competing units, and other parameters related to these factors. Despite 
this, the University is exploring the possibility of installing a CFB boiler to cofire biomass and other waste streams with coal because of the following possible benefits:

1) Waste stream utilization. The CFB boiler would be multi-fuel capable with coal being the primary fuel and supplemented with waste streams. Waste stream disposal costs would be eliminated. For example, sewage sludge is currently landfilled at a cost of $\$ 47 /$ ton.

2) Lower overall fuel costs. This includes using a lower grade coal including bituminous coal refuse (i.e., gob), growing grasses or crops on University land and cofiring in the boiler, accepting biomass and other wastes from the municipality, and being a test site for industry (e.g., Foster Wheeler) to conduct various fuel tests where the test fuel would be used in place of fuels purchased by the University.

3) Higher efficiency boilers.

4) Lower boiler emissions.

5) Possible alternative to spreading manure on fields and the associated odor problem.

6) Potential external funding source for a boiler replacement project. A recent energy assessment for Penn State showed that a coal-fired cogeneration plant was not economically feasible. However, OPP is reconsidering a boiler replacement because there is the possibility that some of the funding may come from other sources, e.g., industrial sponsorship, state and federal agencies.

7) Research component. By being a test site for industry (e.g., Foster Wheeler), not only would there be a decrease in fuel costs but there is the possibility that other operating costs such as labor could be reduced when industry-funded testing occurs.

Penn State's seven boilers are housed at two locations on campus as shown in Figure 1. The four coal-fired boilers and one small natural gas and oil-fired boiler are located at the West Campus Steam Plant (WCSP). There is not any room for installing additional boilers at this location. Two 100,000 pph of steam boilers, designed for natural gas and No. 2 fuel oil, are located at the East Campus Steam Plant (ECSP). This facility is used for peaking purposes. This location has been identified for future boiler expansion. At this time, OPP is interested in installing a CFB boiler with 200,000 pph of steam capacity at the ECSP. This size of a boiler could be installed without extensive upgrades to the current steam, water, and condensate return infrastructure. Final selection of the boiler size will be determined as part of the feasibility study.

\subsection{Project Outline}

The work consists of gathering design-related information, collecting and analyzing representative biofuels, coal, and coal refuse samples, developing a conceptual CFB boiler system design, developing a preliminary three-year test program and associated budget, determining the system design/test program economics, and performing the feasibility study. The work is being performed via the following tasks: 


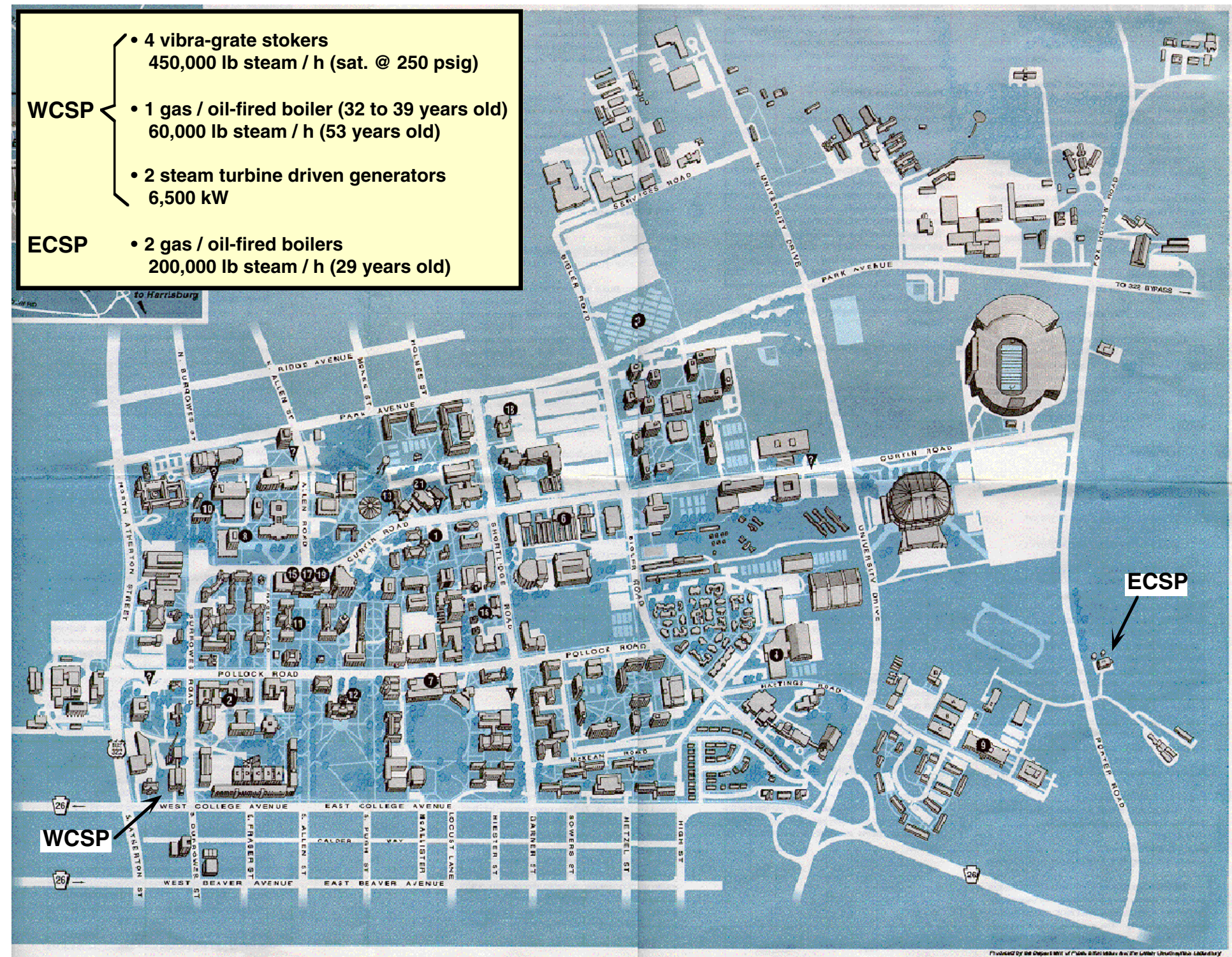

Figure 1. PENN STATE'S WEST CAMPUS AND EAST CAMPUS STEAM PLANTS 
- Task 1. Information and Sample Collection

- Task 2. Biofuels and Biofuel/Coal Characterization

- Task 3. Develop Conceptual Design

- Task 4. Develop Preliminary Test Program/Budget

- Task 5. Determine System/Program Economics

- Task 6. Complete Feasibility Study

- Task 7. Project Management/Reporting

A summary of the activities being performed in each task includes:

Task 1. Information and Sample Collection: System requirements and infrastructure information will be assembled by Penn State and provided to Foster Wheeler. In addition, representative samples of biofuel, coal, and coal refuse will be collected by Penn State and Cofiring Alternatives and provided to Foster Wheeler.

Task 2. Characterize Biofuels and Biofuel/Coal Combinations: Foster Wheeler will characterize the samples collected in Task 1 and use the analyses for assessing issues such as materials handling, deposition, and emissions.

Task 3. Develop Conceptual Design: A CFB boiler system will be designed to address the multiple project objectives. Foster Wheeler will perform the conceptual design with input from Penn State and Cofiring Alternatives.

Task 4. Develop Preliminary Test Program/Budget: A three-year test program will be designed and costed to use the state-of-the-art CFB boiler system for investigating a range of issues when cofiring multiple biofuels and possibly other waste materials. Penn State will develop the preliminary test program with consultation from Foster Wheeler and Cofiring Alternatives.

Task 5. Determine System/Program Economics: Capital and operating costs will be determined. In addition, the availability of funding for the system and test program will be assessed.

Task 6. Complete Feasibility Study: The feasibility study will be completed by incorporating the results from each of the tasks.

Task 7. Project Management/Reporting: The project will be managed and reported per DOE's contractual requirements. Reporting will include the quarterly program/project management and technical progress reports, and a final report.

The status of Tasks 1 through 7 is presented in Sections 2.0 through 8.0, respectively. Section 9.0 discusses miscellaneous activities that were conducted. Activities planned for the next quarterly period are listed in Section 10.0. Acknowledgments are contained in Section 11.0. The project schedule is given in Figure 2, with a description of the milestones contained in Table 1. 


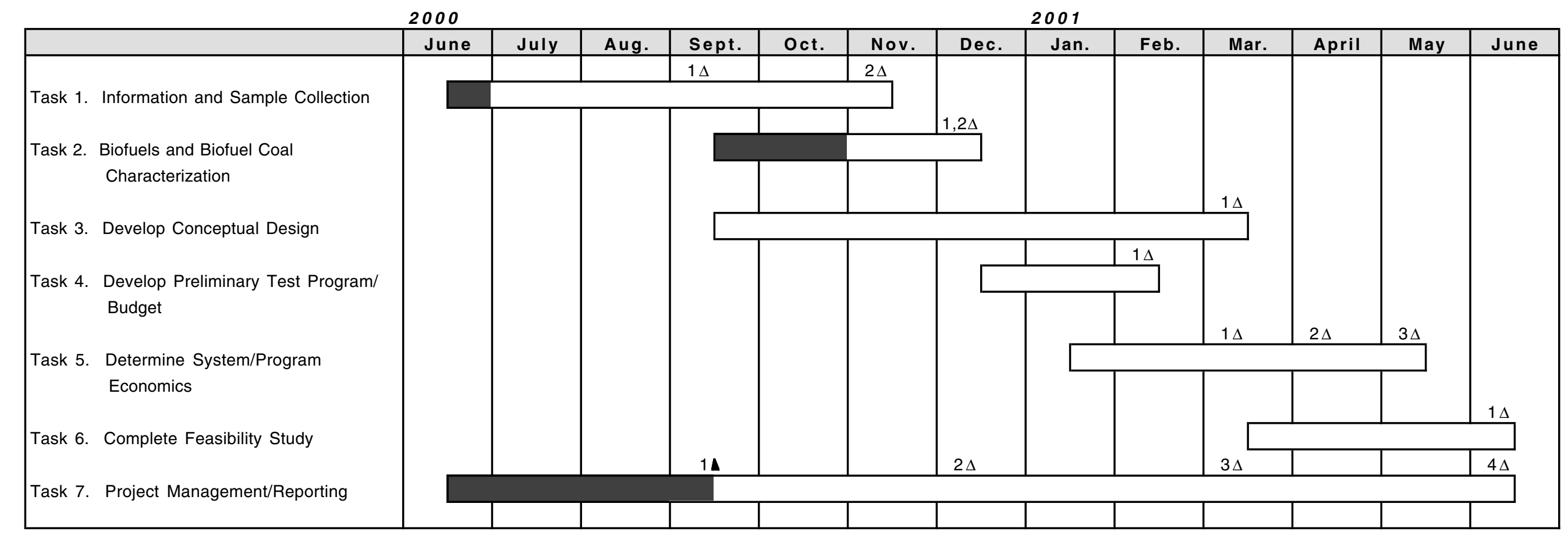

Figure 2. MILESTONE SCHEDULE 
Table 1. Description of Milestones

\begin{tabular}{|c|c|c|c|}
\hline Milestone & Description & $\frac{\begin{array}{c}\text { Planned } \\
\text { Completion }\end{array}}{\underline{\text { Date }}}$ & $\frac{\frac{\underline{\text { Actual }}}{\text { Completion }}}{\underline{\text { Date }}}$ \\
\hline Task 1 , No. 1 & $\begin{array}{l}\text { Assemble system requirements and infrastructure } \\
\text { information }\end{array}$ & $09 / 15 / 00$ & \\
\hline Task 1, No. 2 & Collect representative biofuel and coal samples & $11 / 15 / 00$ & \\
\hline Task 2, No. 1 & Complete characterization of biofuel samples & $12 / 15 / 00$ & \\
\hline Task 2, No. 2 & Complete characterization of biofuel/coal samples & $12 / 15 / 00$ & \\
\hline Task 3, No. 1 & Complete conceptual design & 03/15/01 & \\
\hline Task 4, No. 1 & Develop preliminary task program/budget & $02 / 15 / 01$ & \\
\hline Task 5, No. 1 & Determine capital cost & $03 / 15 / 01$ & \\
\hline Task 5, No. 2 & Determine operating costs & 04/15/01 & \\
\hline Task 5, No. 3 & Assess availability of funding & $05 / 15 / 01$ & \\
\hline Task 6, No. 1 & Complete feasibility study & $06 / 15 / 01$ & \\
\hline Task 7, No. 1 & $\begin{array}{l}\text { Prepare program/project management and technical } \\
\text { report } 1\end{array}$ & $09 / 15 / 00$ & $10 / 15 / 00$ \\
\hline Task 7, No. 2 & $\begin{array}{l}\text { Prepare program/project management and technical } \\
\text { report } 2\end{array}$ & $12 / 15 / 00$ & \\
\hline Task 7, No. 3 & $\begin{array}{l}\text { Prepare program/project management and technical } \\
\text { report } 3\end{array}$ & $03 / 15 / 01$ & \\
\hline Task 7, No. 4 & $\begin{array}{l}\text { Prepare program/project management and technical } \\
\text { report 4; prepare final report }\end{array}$ & 06/14/01 & \\
\hline
\end{tabular}




\subsection{Task 1. Information and Sample Collection}

Subcontracts are still being negotiated with Foster Wheeler and Cofiring Alternatives; consequently, no work has been done by either company during this reporting period. Therefore, no system requirements and infractructure information was assembled by Penn State and provided to Foster Wheeler. Likewise, no discussions or sample collection have occurred with Cofiring Alternatives.

Penn State started assessing the types and quantities of potential feedstocks and collected samples of them for analysis (see Section 3.0). In developing the proposal, OPP prepared a list of waste and by-product streams that were produced at the University Park Campus during 1998, which are listed in Table 2. The original list has been scrutinized in much detail and has been modified after numerous conversations and meetings with personnel from OPP and the College of Agricultural Sciences. A revised list is contained in Table 3.

The main differences between the original list and the new one is that:

1) Materials of unknown quantity have been removed;

2) Some materials have been combined (e.g., leaves and manure are mixed at the animal barns);

3) Some animal wastes have been added;

4) The list has been expanded to include wood waste from the surrounding region;

5) All recyclable materials have been removed (e.g., cardboard, newspaper);

6) Dead animals have been removed because they are currently disposed of in a permitted incinerator on Campus;

7) Garbage has been removed; and

8) Food waste has been removed because a portion is being composted with plans for the remaining portion to be composted.

Photographs of some of the types of biomass are shown in Figures 3 through 7, which are examples of the sewage sludge, dairy tie-stall barn manure, sheep manure, miscellaneous manure from the covered manure barn, and red oak shavings, respectively. A photograph of each of the samples collected is provided in Appendix A.

\subsection{Task 2. Biofuels and Biofuel/Coal Characterization}

Analysis of the biofuels started during this reporting period. Appendix A contains the results of the analyses conducted to-date. The analyses consist of:

1) Proximate analysis;

2) Ultimate analysis;

3) Higher heating value;

4) Bulk density (where appropriate);

5) Chlorine content (where appropriate); and

6) Rheological characteristics (where appropriate). 
Table 2. Waste and By-Product Streams that were Produced at the University Park Campus during 1998

\begin{tabular}{|c|c|}
\hline Material & Quantity (tons) \\
\hline \multicolumn{2}{|l|}{ Biomass Waste/ By-Products } \\
\hline Bedding/ manure & 10,000 \\
\hline Wood waste/ brush & 150 \\
\hline Leaves - Penn State & 150 \\
\hline Pallets & 92 \\
\hline Spoiled hay & small amount \\
\hline Spoiled feed & small amount \\
\hline Grass clippings & small amount \\
\hline Excess lumber & unknown small amount \\
\hline Woodchips/ sawdust & unknown small amount \\
\hline Chicken litter & unknown small amount \\
\hline \multicolumn{2}{|l|}{ Other Wastes } \\
\hline Garbage & 6,719 \\
\hline Bottom ash & 6,394 \\
\hline Fly ash & 1,400 \\
\hline Paper & 736 \\
\hline Cardboard & 472 \\
\hline Sewage sludge & 360 \\
\hline Newspaper & 200 \\
\hline Dead animals & 95 \\
\hline Food waste & 93 \\
\hline Used oil & 14 \\
\hline Tires & 5 \\
\hline Agricultural plastics - animal feed bags & 5 \\
\hline Agricultural plastics - horticulture use & 2 \\
\hline
\end{tabular}


Table 3. Potential CFB Feedstocks

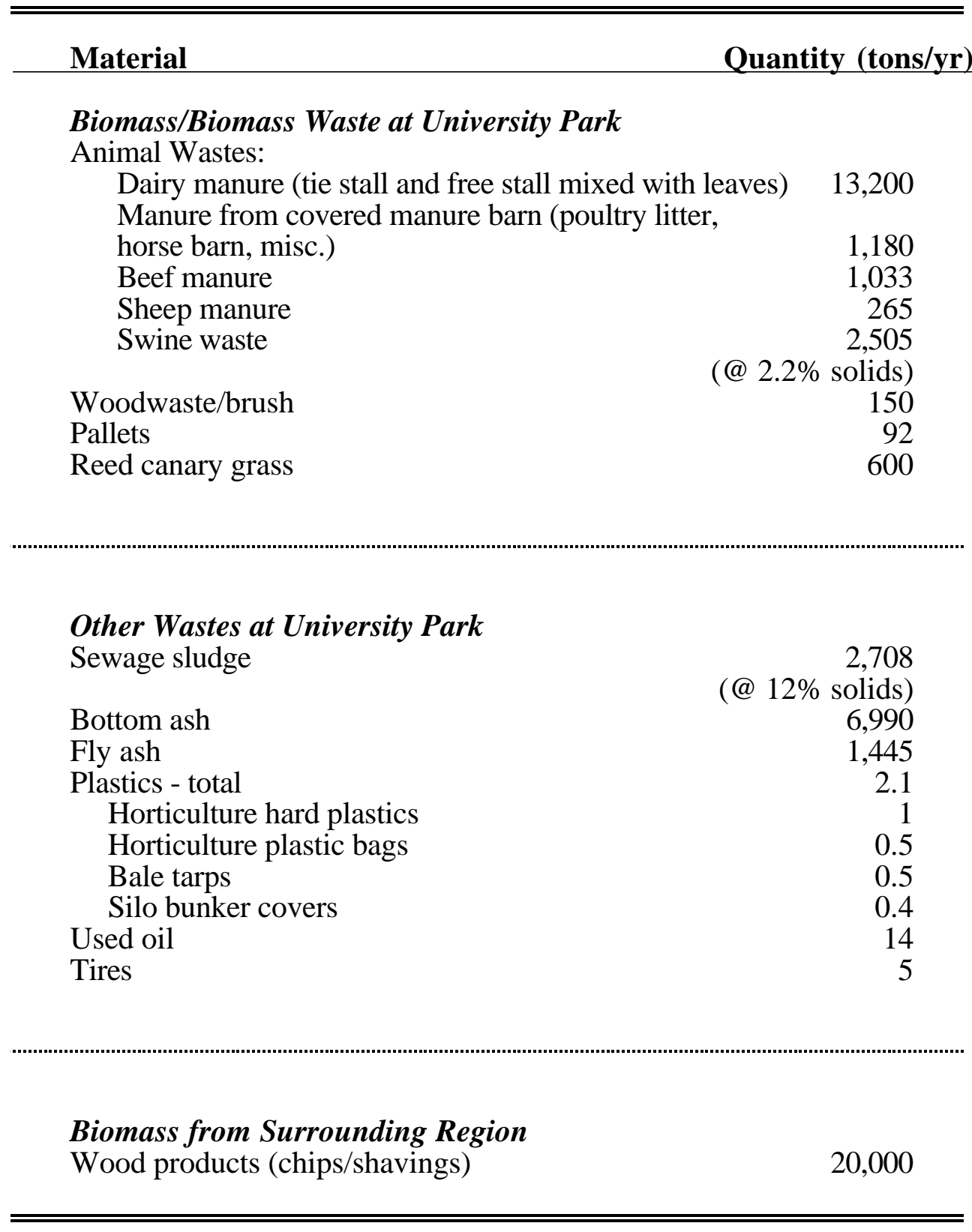




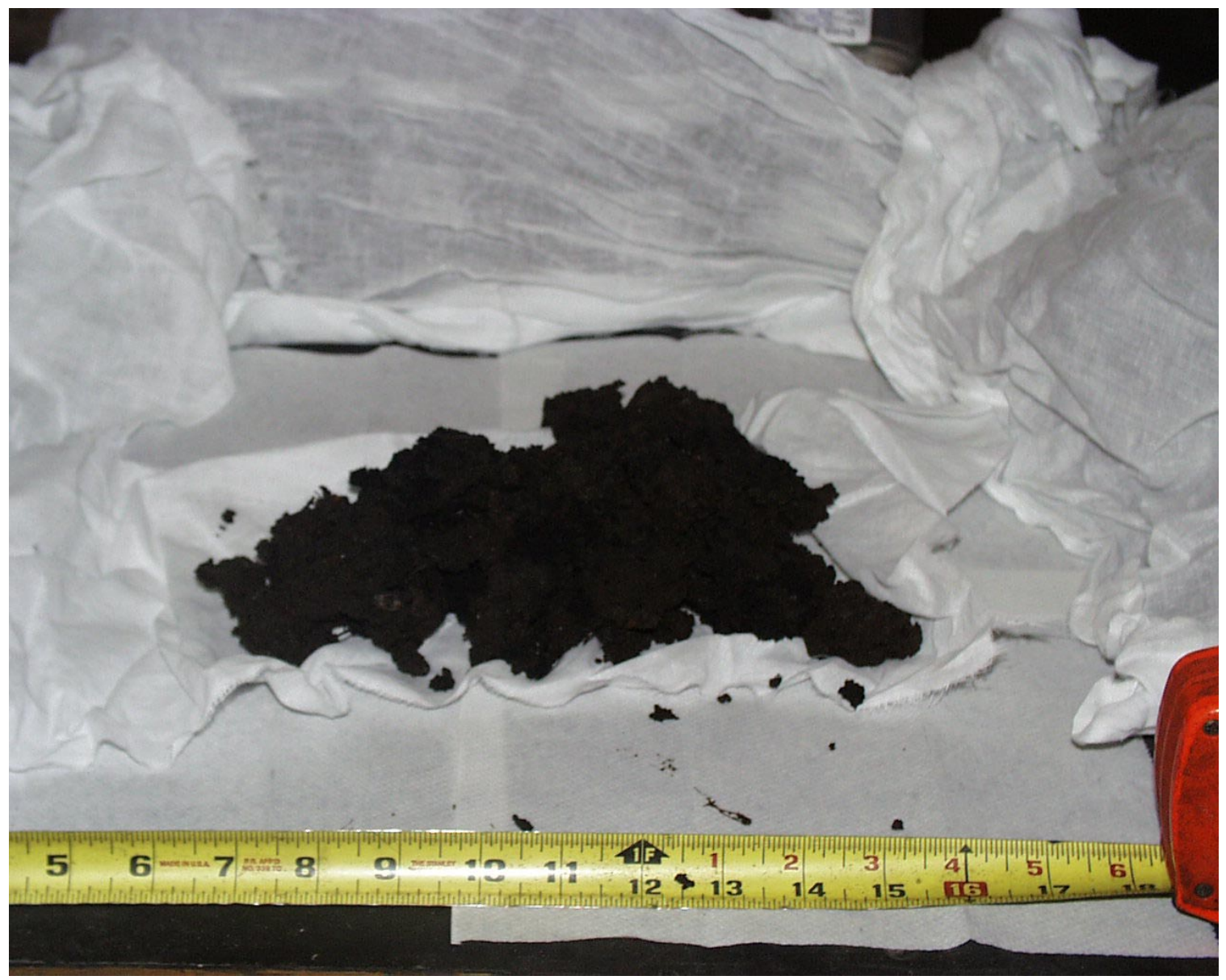

Figure 3. PHOTOGRAPH OF SEWAGE SLUDGE SAMPLE 


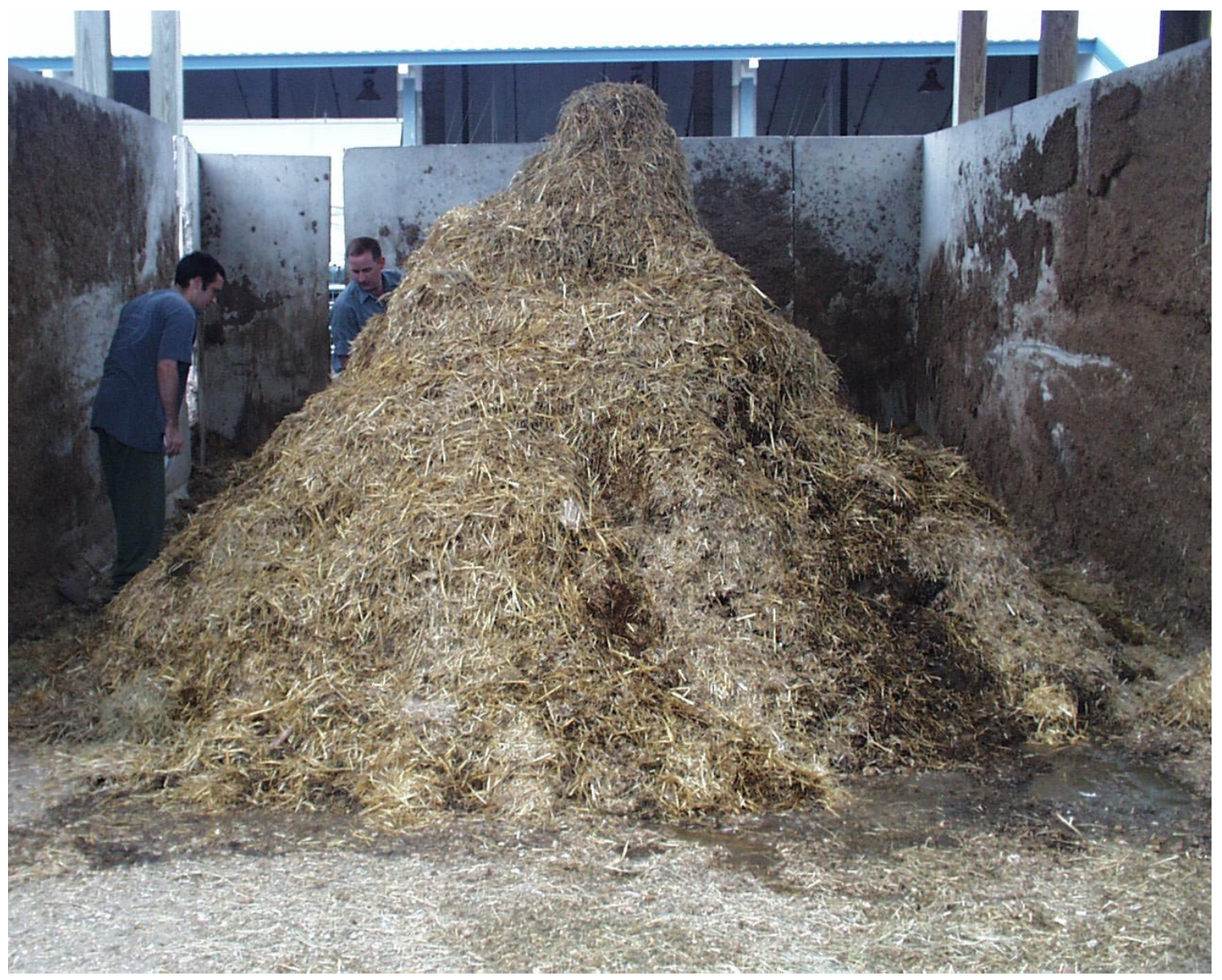

Figure 4. PHOTOGRAPH OF DAIRY TIE-STALL MANURE 


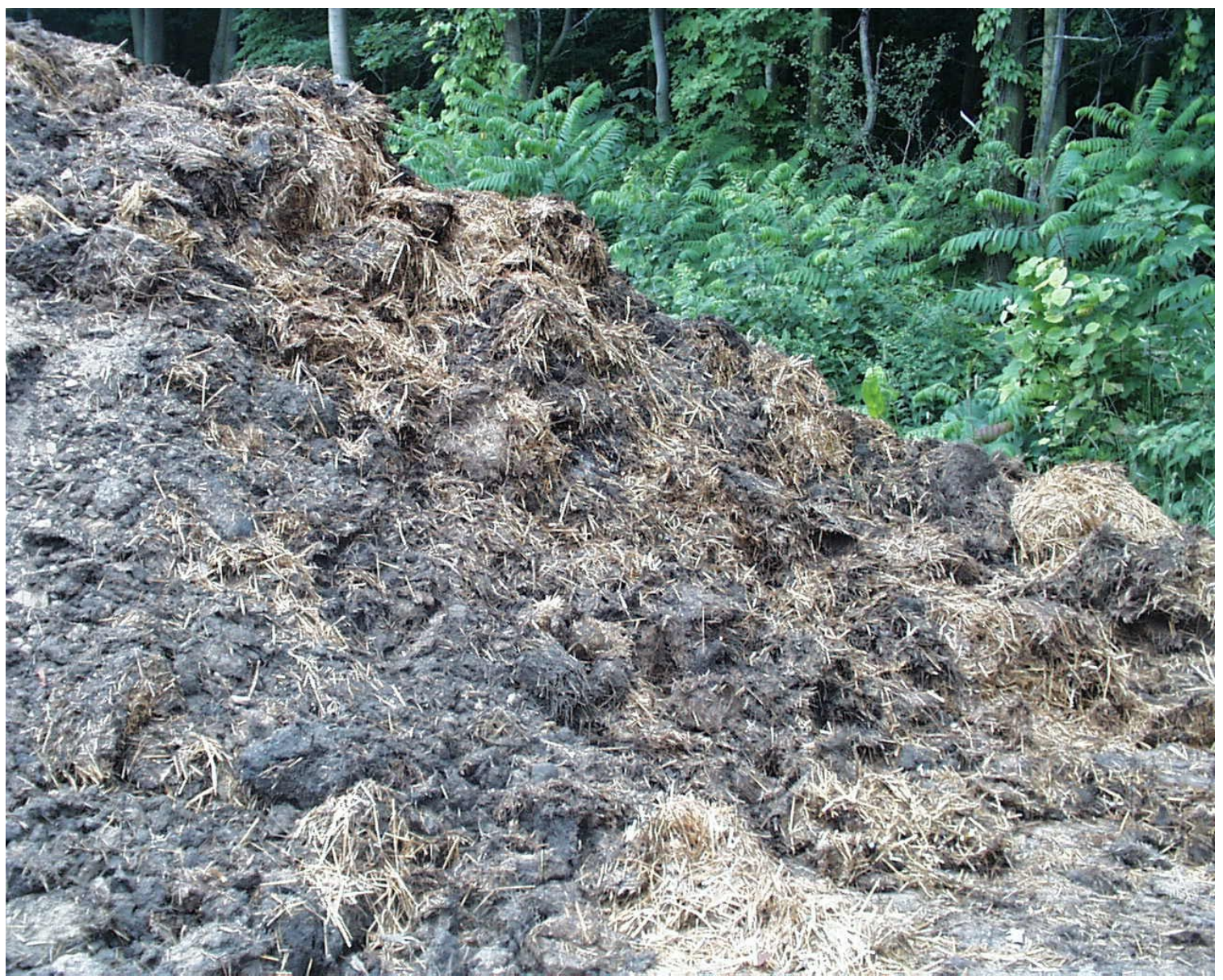

Figure 5. PHOTOGRAPH OF SHEEP MANURE 


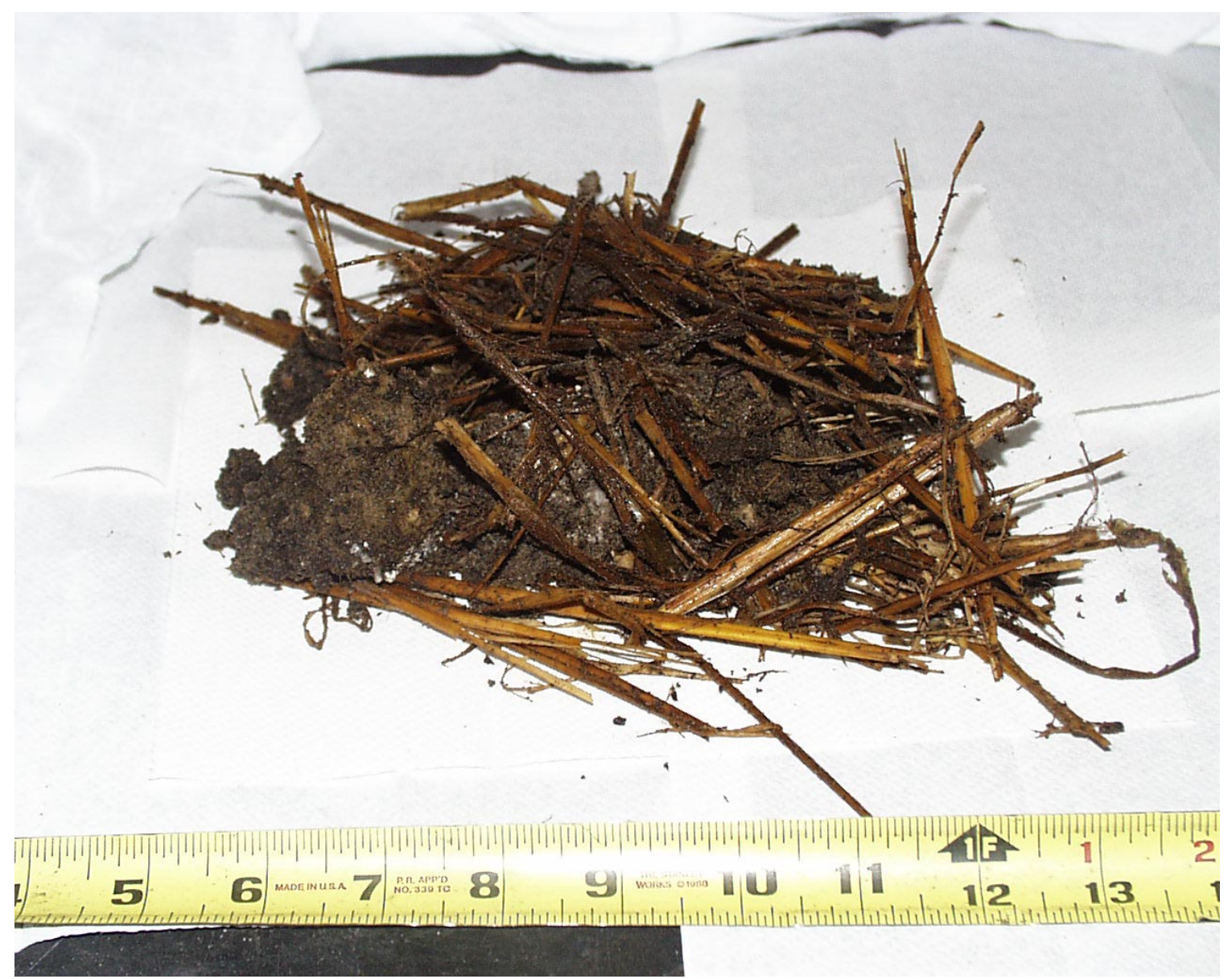

Figure 6. PHOTOGRAPH OF MANURE FROM THE COVERED MANURE BARN 


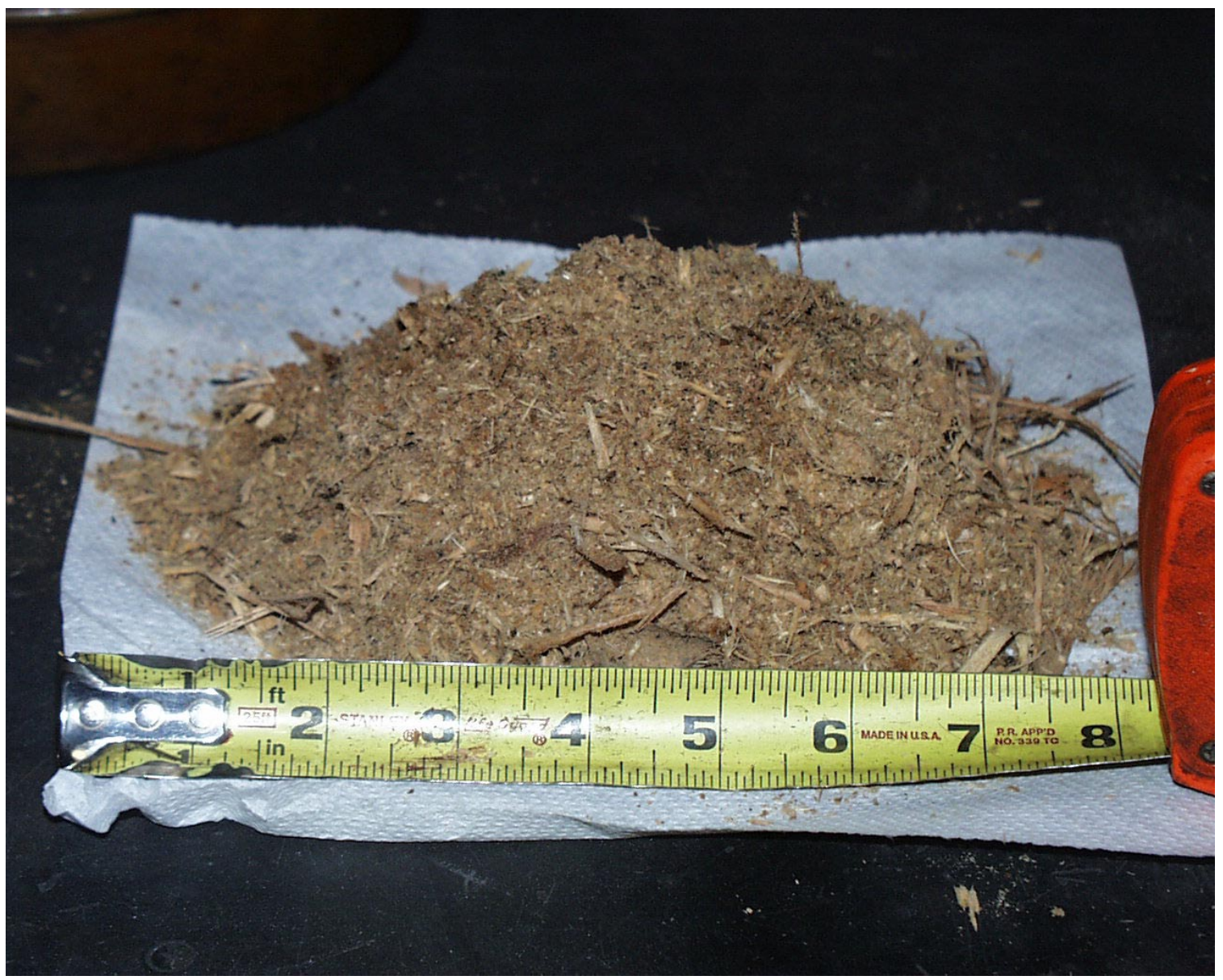

Figure 7. PHOTOGRAPH OF RED OAK SHAVINGS 
Chemical fractionation analysis is presently being performed on the following samples to determine the mode of occurrence of the certain elements within the biomass samples:

1) Pine shavings;

2) Red oak shavings;

3) Dairy tie-stall manure;

4) Dairy free-stall manure;

5) Miscellaneous manure (mixture of various small-quantity manure streams that are collected at a central storage barn;

6) Sewage sludge;

7) Sheep manure;

8) Reed canary grass;

9) Bottom ash; and

10) Fly ash.

These samples are at various stages of fractionation and analysis. The final results will be reported in the next quarterly report.

\subsection{Task 3. Develop Conceptual Design}

No work was performed in Task 3 during this reporting period.

\subsection{Task 4. Develop Preliminary Test Program/Budget}

No work was performed in Task 4 during this reporting period.

\subsection{Task 5. Determine System/Program Economics}

No work was performed in Task 5 during this reporting period.

\subsection{Task 6. Complete Feasibility Study}

No work was performed in Task 6 during this reporting period.

\subsection{Task 7. Project Management/Reporting}

During this reporting period, a Hazardous Substance Plan and a Milestone Plan were prepared and submitted July 5, 2000 and July 14, 2000, respectively.

In addition, subcontracts were prepared for Foster Wheeler Development Corporation and Cofiring Alternatives. The subcontracts are currently under negotiation with both companies.

\subsection{Miscellaneous Activities}

Two relevant activities were performed during this reporting period. The first was a trip to the P.H. Gladfelter Company's plant in Spring Grove, Pennsylvania on July 25, 
2000 to tour the facility, which cofires coal and wood wastes. A contingency from Penn State comprised of Robert Cooper (OPP, Manager of Engineering Services), Douglas Donovan (OPP, Energy Program Engineer), Samuel Duck (OPP, Steam Plant Supervisor), Matthew Lapinsky (OPP, Environmental Engineer), Bruce Miller (The Energy Institute), and William Serencsits (OPP, Utility Systems Engineer) met with Neil Raskin (Foster Wheeler) and Peter Kline (P.H. Gladfelter, Assistant Manger, Power \& Steam) to tour the facility and discuss materials handling and combustion issues.

William Serencsits was invited to and attended Foster Wheeler's annual Customer's Conference in San Diego, California from August 16-18, 2000. The focus of the conference was to provide information on current CFB projects, maintenance and operation problems, and new products and services.

\subsection{Next Quarterly Activities}

During the next reporting period, the following will be done:

- Subcontracts will be executed with Foster Wheeler and Cofiring Alternatives;

- The collection and analysis of all potential feedstocks will be completed; and

- System requirements and infractructure information will be assembled by Penn State and provided to Foster Wheeler.

\subsection{Acknowledgements}

Funding for the work was provided by the U.S. Department of Energy under Grant No. DE-FG26-00NT40809. The project is being managed by the U.S. Department of Energy, National Energy Technology Laboratory (Pittsburgh). Philip Goldberg of NETL is the project manager.

Robert Cooper and Doug Donovan from Penn State's OPP are acknowledged for providing guidance on Penn State's utility needs and long-range plans.

William Scerencsits and John Gaudlip from Penn State's OPP, and Randy Swope, Glen Cauffman, Bill Lamont, and Jim Garthe from Penn State's College of Agricultural Sciences are acknowledged for the assistance in identifying, quantifying, and sampling various potential feedstocks. 
Appendix A. Analysis and Photographs of Potential Feedstocks 


\section{A: Digester Effluent}
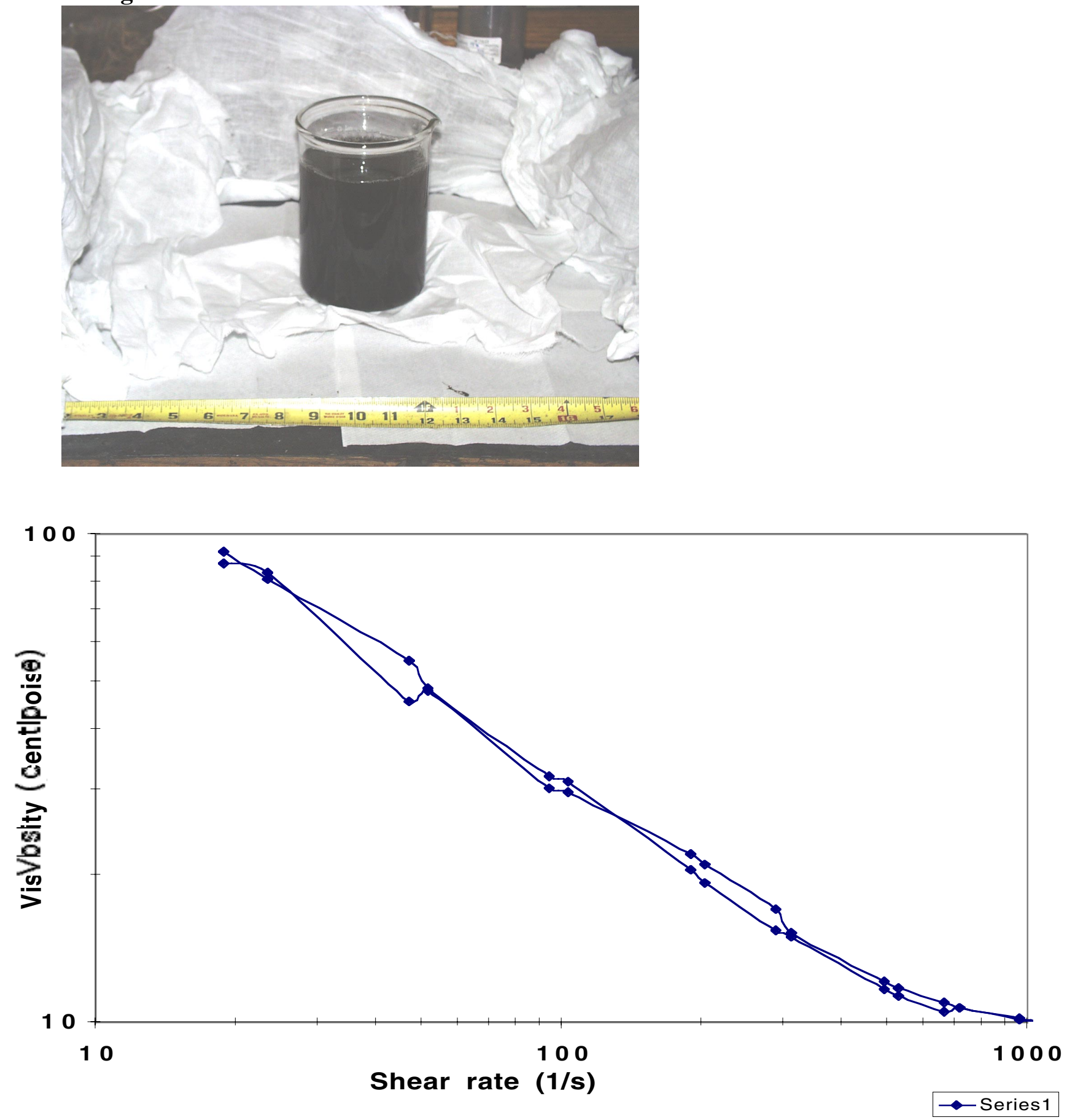

28-31 cp at 100/s 


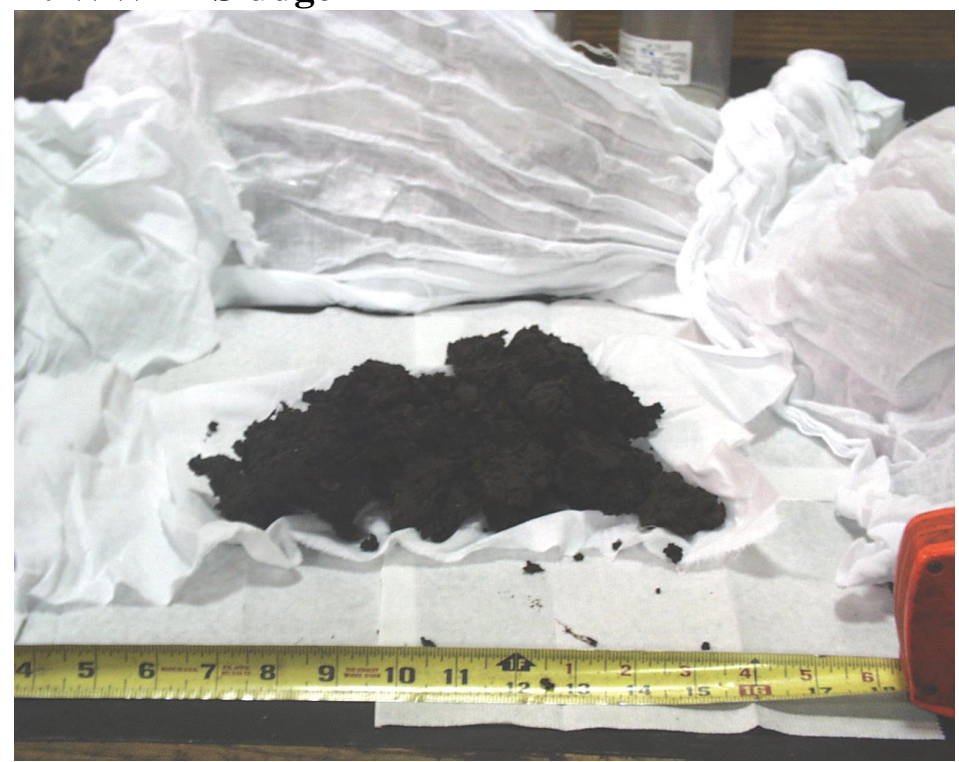

2,708 tons/yr @ $12 \%$ solids = 325 dry tons/yr

Rep $1 \quad \operatorname{Rep} 2$

77.2

76.9

Rep 3

$\operatorname{Rep} 4$

Moisture

49.6

46.9

3.5

Fixed Carbon

Ultimate Analysis (wt. \%, d.b.)

\section{Carbon}

Hydrogen

Nitrogen

Sulfur

Oxygen

HHV (Btu/lb)

Bulk Density ${ }^{\mathrm{b}}$ (g/cc)

$\left(\mathbf{l b} / \mathbf{f t}^{3}\right)$

${ }^{a}$ Dry Basis

${ }^{\mathrm{b}}$ Determined from Entire Sample

${ }^{c}$ Not Determined
30.3

4.3

4.1

1.1

13.3

4,325

1.0

62.4
48.3

48.2

3.5

N.D.

N.D.

N.D.

N.D.

N.D.

5,268

4,678

N.D.

N.D.

N.D.

N.D.

N.D.

N.D.

N.D.

N.D.

N.D.

N.D.

N.D.

N.D.

N.D.

N.D.

N.D. 


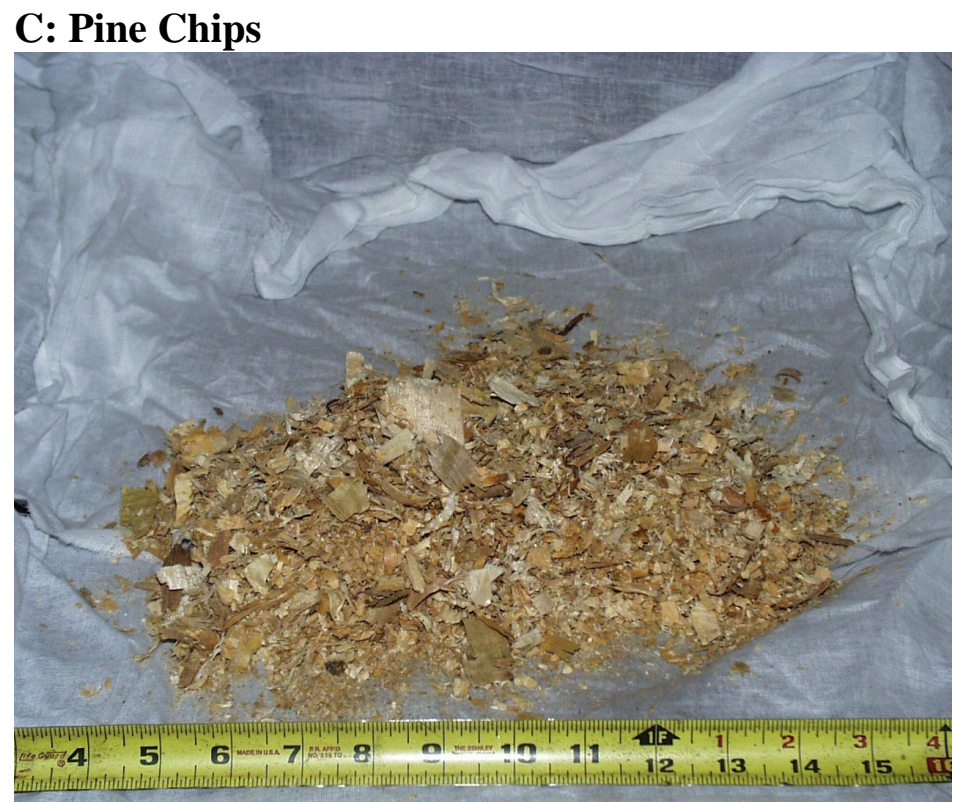

Content assumed same as pine shavings

Bulk density $=0.10 \mathrm{~g} / \mathrm{cc}$

20,000 tons $/ y r @ 40 \%$ moisture $=12,000$ dry tons $/ y r$ 


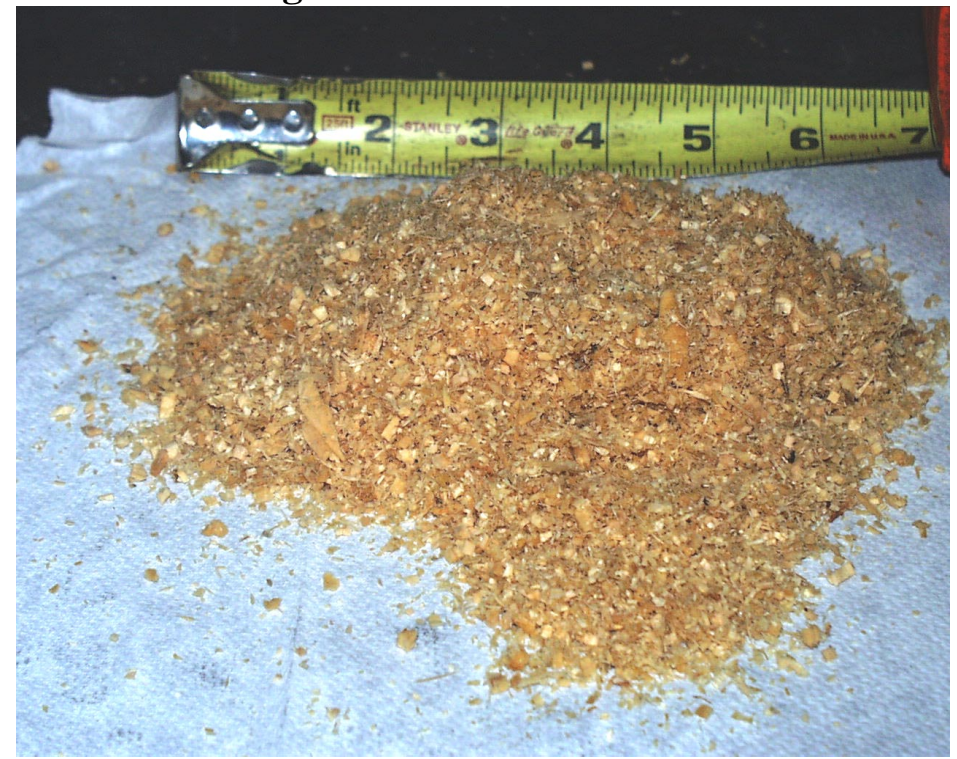

12,000 dry tons/yr

Moisture

Rep 1

45.0

84.7

0.1

15.2

Fixed Carbon

Ultimate Analysis (wt. \%, d.b.)

\section{Carbon}

Hydrogen

Nitrogen

Sulfur

Oxygen

HHV (Btu/lb)

Bulk Density ${ }^{\mathrm{b}}$ (g/cc)

$\left(\mathbf{l b} / \mathbf{f t}^{3}\right)$

\footnotetext{
${ }^{a}$ Dry Basis

${ }^{\mathrm{b}}$ Determined from Entire Sample

${ }^{c}$ Not Determined
}

49.1

6.4

0.2

0.2

44.0

8,502

0.19

11.9
$\operatorname{Rep} 2$

46.3

83.0

0.0

17.0

N.D.

N.D.

N.D.

N.D.

N.D.

8,422
8,197

N.D.

N.D.

N.D.

N.D.

N.D.

81.9

0.0

18.1

17.8

N.D.

N.D.

N.D.

N.D.

N.D.

N.D.

N.D. ${ }^{\mathrm{c}}$

8,197 N.D.


E: Fly ash

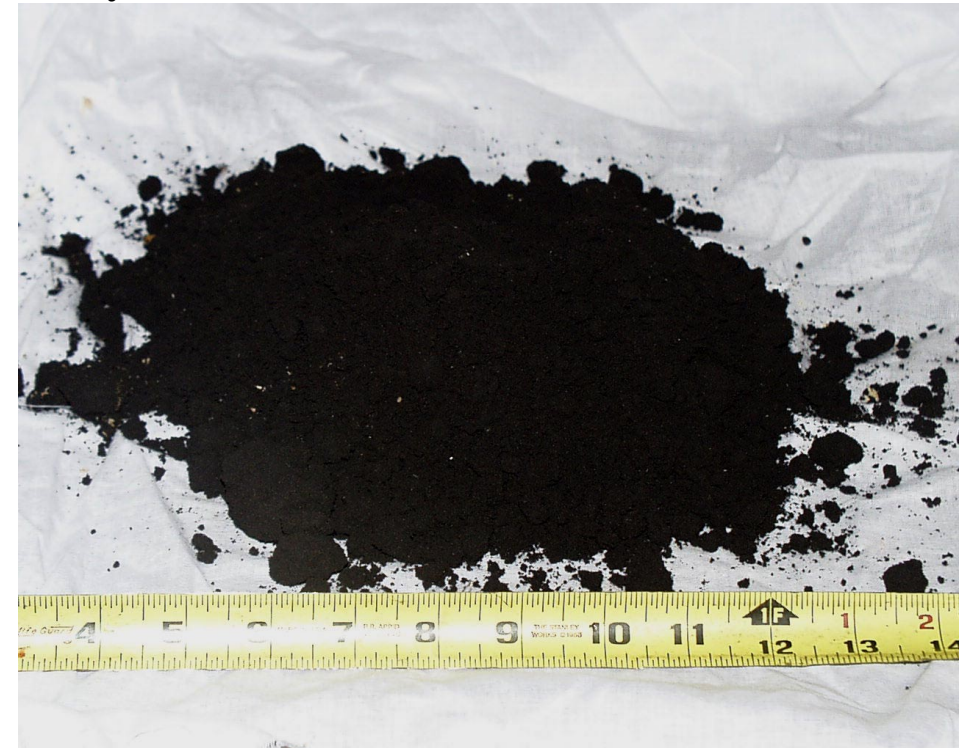

1,445 tons/yr @ 23\% moisture=1,113 dry tons $/ y r$

$\begin{array}{lllll} & \text { Rep 1 } & \text { Rep 2 } & \text { Rep 3 } & \text { Rep 4 } \\ \text { Moisture } & 22.8 & 24.5 & 23.8 & \text { N.D. }{ }^{\text {c }}\end{array}$

Proximate Analysis (wt.\%, d.b. ${ }^{\mathrm{a}}$ )

Volatile Matter

Ash

Fixed Carbon

Ultimate Analysis (wt. \%, d.b.)

\section{Carbon}

Hydrogen

Nitrogen

Sulfur

Oxygen

HHV (Btu/lb)

Bulk Density ${ }^{\mathrm{b}}$ (g/cc)

$\left(\mathbf{l b} / \mathbf{f t}^{3}\right)$

22.0

0.3

0.3

1.2

2.4

1,737

0.72

11.9
7.2

74.1

18.7

23.5

0.1

0.2

0.9

1.2

1,700

1,520

0.1

0.3

0.7

4.0

72.2

18.1

8.2

73.4

17.5

21.0

0.1

0.2

0.6

4.6

1,436

\footnotetext{
${ }^{a}$ Dry Basis

${ }^{\mathrm{b}}$ Determined from Entire Sample

${ }^{\mathrm{c}}$ Not Determined
} 


$$
i
$$


F: Bottom Ash

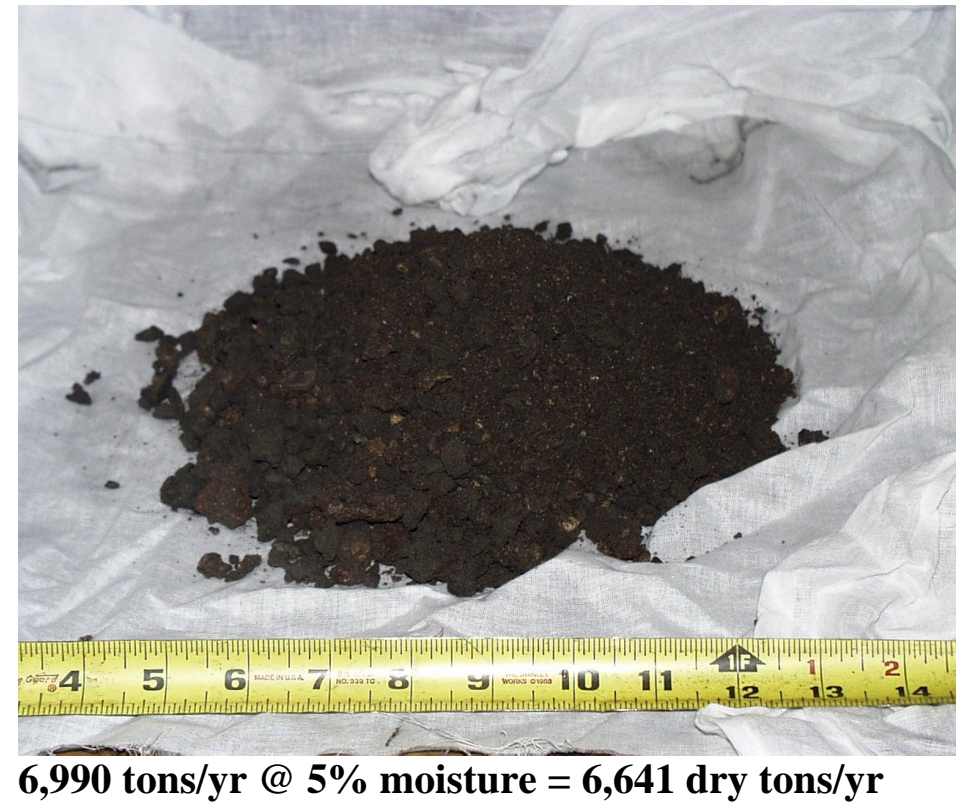

Moisture

Rep 1

4.9

Rep 2

4.8

Proximate Analysis (wt.\%, d.b. ${ }^{a}$ )

Volatile Matter

Ash

Fixed Carbon

Ultimate Analysis (wt. \%, d.b.)

\section{Carbon}

Hydrogen

Nitrogen

Sulfur

Oxygen

HHV (Btu/lb)

Bulk Density $^{\text {b }}$ (g/cc)

$\left(\mathbf{l b} / \mathbf{f t}^{3}\right)$
1.9

73.4

24.7

31.5

0.0

0.6

0.2

$-5.7$

2,341

0.84

52.4
1.8

73.1

25.1

31.3

0.1

0.5

0.2

$-5.2$

2,076

0.8

72.4

26.8

1.4

72.1

26.5

28.0

0.1

0.6

0.2

$-1.3$

$1,863 \quad 1,798$

N.D.

0.2

0.6
$\operatorname{Rep} 5$

N.D.

N.D.

N.D.

N.D.

26.9

0.0

0.3

0.2

N.D.

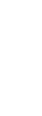

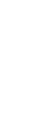




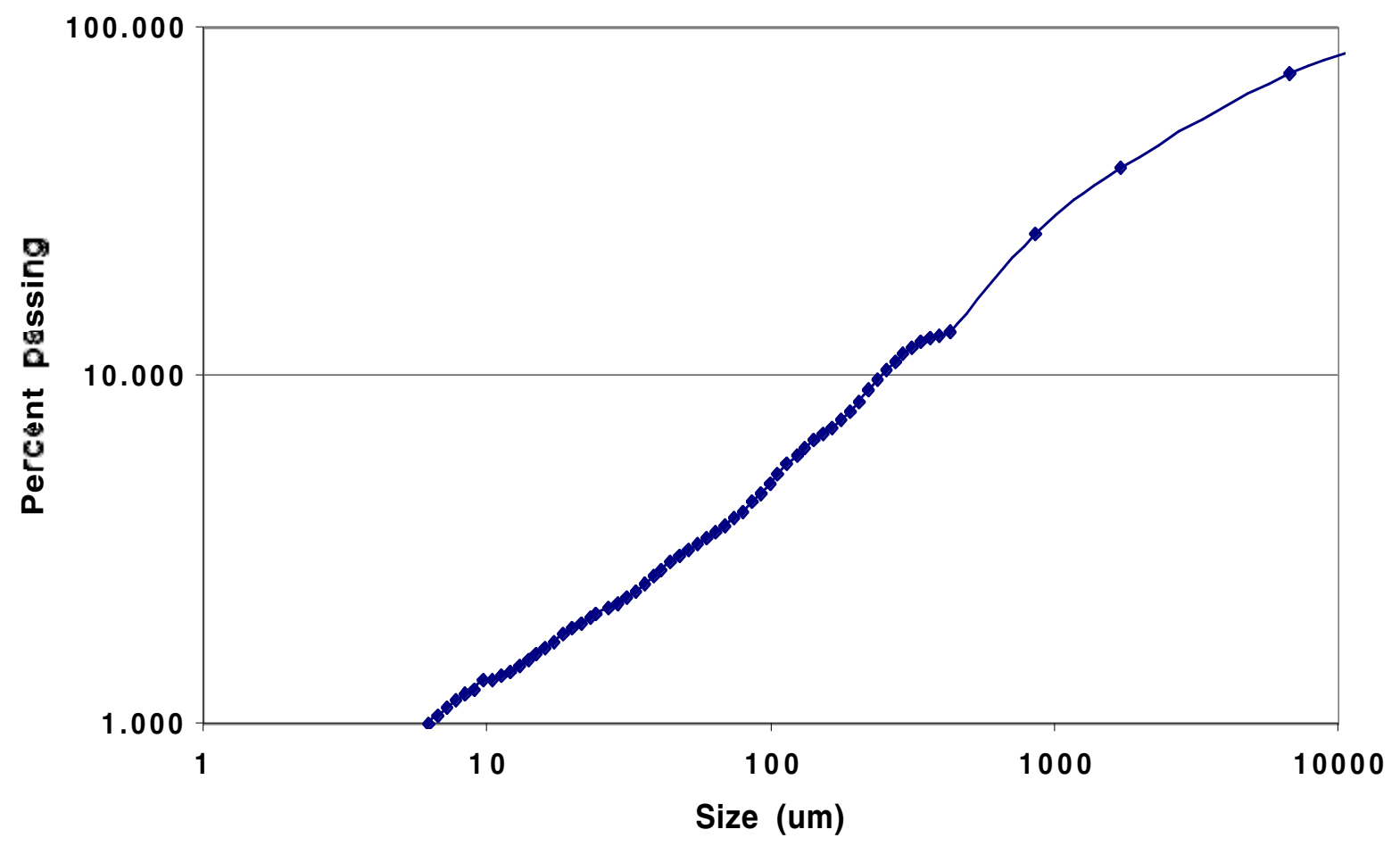


G: Hard Plastic (from horticulture dept.)

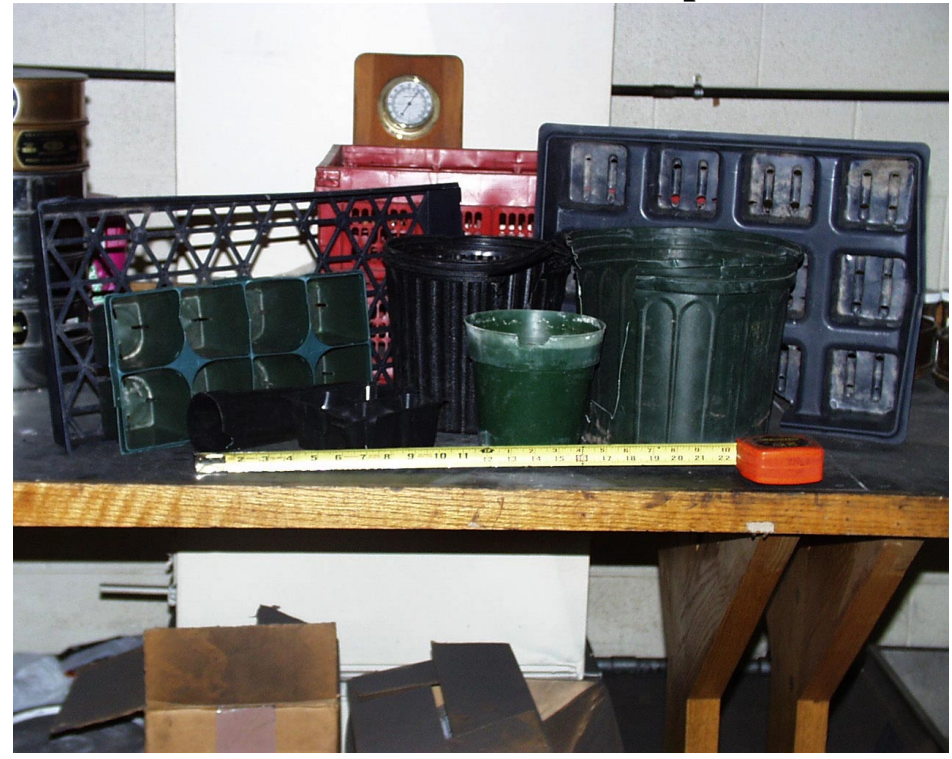

$400 \mathrm{lb} / \mathrm{yr}$

Moisture

Proximate Analysis (wt.\%, d.b. ${ }^{a}$ )

Volatile Matter

Ash

Fixed Carbon

Ultimate Analysis (wt. \%, d.b.)

\section{Carbon}

Hydrogen

Nitrogen

Sulfur

Oxygen

HHV (Btu/lb)

Chlorine Content (ppm)

${ }^{a}$ Dry Basis

${ }^{\mathrm{b}}$ Not Determined
Rep 1

0.2

96.1

3.8

0.1

86.2

10.9

0.2

0.1

$-1.2$

18,240

216

96.6

3.4

0.0

$\operatorname{Rep} 2$

N.D. ${ }^{b}$

Rep 3

N.D.

N.D.

N.D.

N.D.

80.6

14.0

0.1

0.1

$-2.0$

10.9

0.2

0.1

$-2.0$

18,549

18,500

N.D.

N.D.
N.D.

N.D.

Rep 4

N.D.

N.D.

N.D.

N.D.

86.1

11.8

0.1

0.1 
H: Plastic Bags (from horticulture dept.)

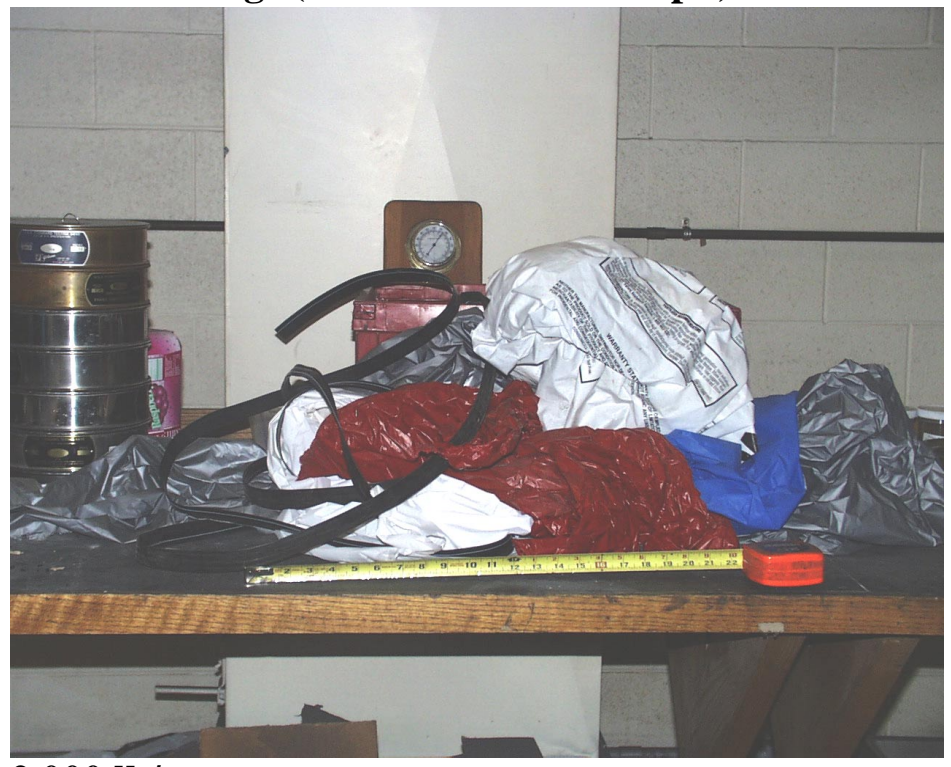

$2,000 \mathrm{lb} / \mathrm{yr}$

$\begin{array}{lllll} & \text { Rep 1 } & \text { Rep 2 } & \text { Rep 3 } & \text { Rep 4 } \\ \text { Moisture } & 0.1 & \text { N.D. }{ }^{\text {b }} & \text { N.D. } & \text { N.D. }\end{array}$

Proximate Analysis (wt.\%, d.b.)

Volatile Matter

Ash

Fixed Carbon

Ultimate Analysis (wt. \%, d.b.)

\section{Carbon}

Hydrogen

Nitrogen

Sulfur

Oxygen

HHV (Btu/lb)

Chlorine Content (ppm)

${ }^{a}$ Dry Basis

${ }^{\mathrm{b}}$ Not Determined
96.9

2.7

0.4

86.1

14.0

0.3

0.0

$-3.1$

19,474

334

96.5

3.3

0.2

81.4

13.3

0.3

0.0

1.7

19,170

N.D.

N.D.

N.D.

N.D.

N.D.

N.D.

N.D.

N.D.

\section{9}

13.0

0.1

0.0

N.D.

N.D.

N.D. 


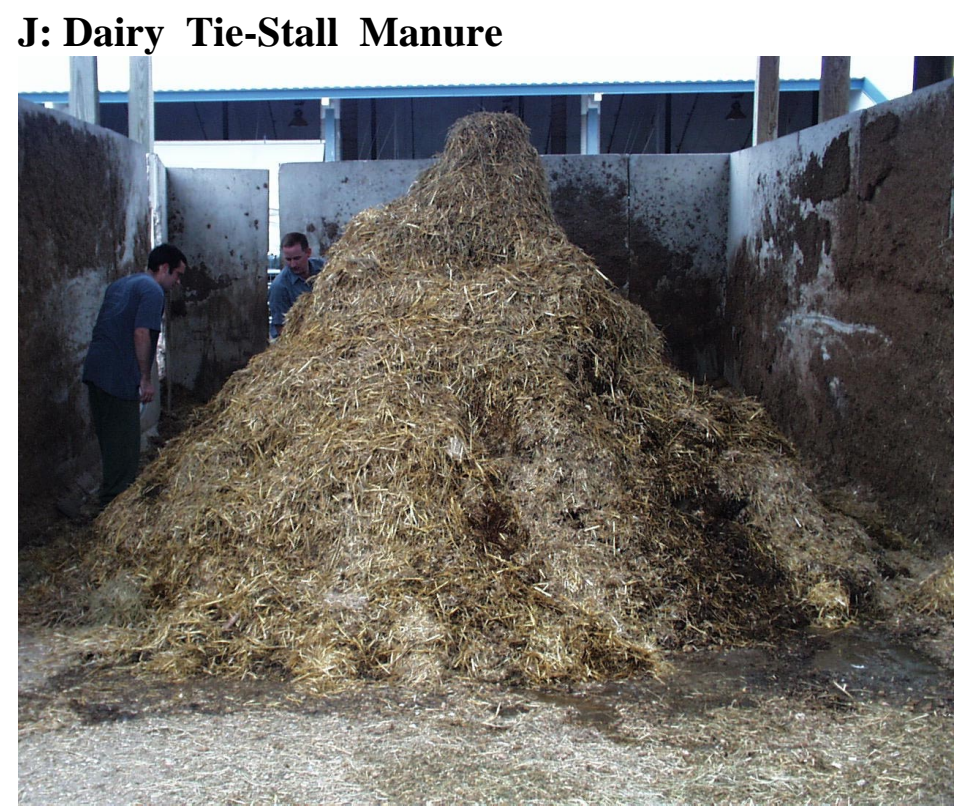

13,200 tons/yr along with free-stall @ 65\% moisture =4,620 dry tons/yr

Moisture

Proximate Analysis (wt.\%, d.b. $\left.{ }^{a}\right)$

Volatile Matter

Ash

Fixed Carbon

Ultimate Analysis (wt. \%, d.b.)

\section{Carbon}

Hydrogen

Nitrogen

Sulfur

Oxygen

HHV (Btu/lb)

Bulk Density ${ }^{\mathrm{b}}$ (g/cc)

$\left(\mathbf{l b} / \mathbf{f t}^{3}\right)$

Rep 1

64.7

76.0

6.0

18.1

48.6

5.8

1.4

0.1

38.1

8,203

0.40

25.0
Rep 2

64.4

74.6

5.7

19.7

N.D.

N.D.

$48.1 \quad$ N.D.

$5.8 \quad$ N.D.

$1.1 \quad$ N.D.

$0.1 \quad$ N.D.

$39.2 \quad$ N.D.

7,850 N.D.

${ }^{a}$ Dry Basis

${ }^{\mathrm{b}}$ Determined from Entire Sample

${ }^{\mathrm{c}}$ Not Determined 
K: Dairy Free-Stall Manure

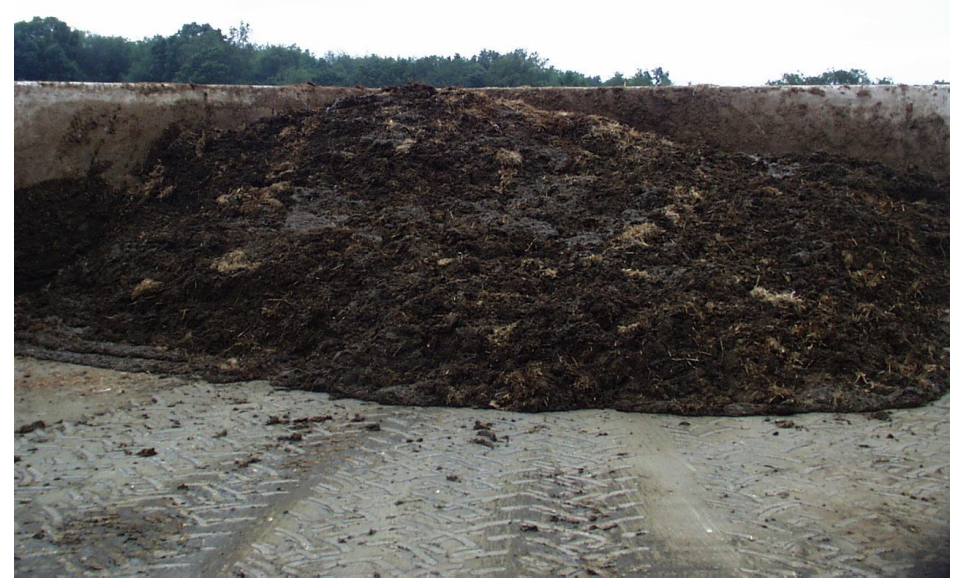

13,200 tons/yr along with tie-stall @ 65\% moisture = 4,620 dry tons/yr

$\begin{array}{llll} & \text { Rep 1 } & \text { Rep 2 } & \text { Rep 3 } \\ \text { Moisture } & 69.8 & 69.6 & 71.5\end{array}$

Proximate Analysis (wt.\%, d.b.)

$\begin{array}{llll}\text { Volatile Matter } & 30.1 & 31.1 & \text { N.D. }{ }^{\mathrm{c}} \\ \text { Ash } & 62.5 & 62.2 & \text { N.D. } \\ \text { Fixed Carbon } & 7.4 & 6.7 & \text { N.D. }\end{array}$

Ultimate Analysis (wt. \%,d.b.)

\begin{tabular}{|c|c|c|}
\hline Carbon & 22.6 & 21.7 \\
\hline Hydrogen & 2.9 & 2.8 \\
\hline Nitrogen & 1.1 & 1.1 \\
\hline Sulfur & 0.1 & 0.1 \\
\hline Oxygen & 10.8 & 12.1 \\
\hline HHV (Btu/lb) & 3,644 & 3,953 \\
\hline $\begin{array}{r}\text { Bulk Density }^{\mathrm{b}}(\mathrm{g} / \mathrm{cc}) \\
\left(\mathbf{l b} / \mathbf{f t}^{3}\right)\end{array}$ & $\begin{array}{l}0.81 \\
50.5\end{array}$ & \\
\hline
\end{tabular}

${ }^{a}$ Dry Basis

${ }^{\mathrm{b}}$ Determined from Entire Sample

${ }^{\mathrm{c}}$ Not Determined 


\section{L: Mulch Hay}

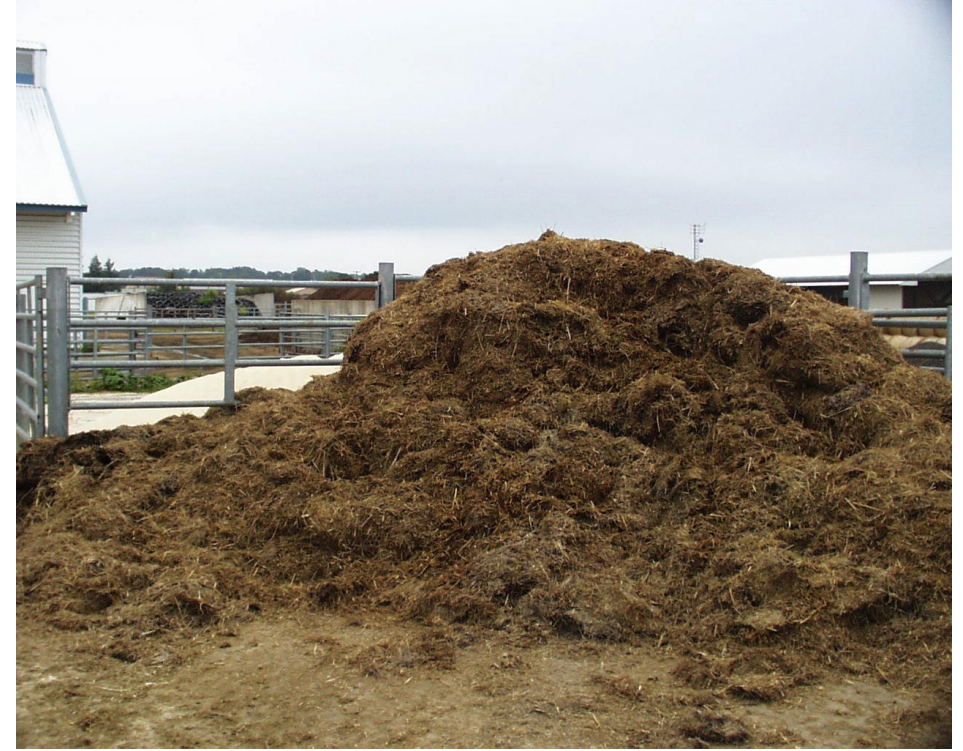

Mixed into J and $\mathrm{K}$

$\begin{array}{llll} & \text { Rep 1 } & \text { Rep 2 } & \text { Rep 3 } \\ \text { Moisture } & 19.5 & 19.3 & 18.3\end{array}$

Proximate Analysis (wt.\%, d.b. ${ }^{a}$ )

Volatile Matter

Ash

Fixed Carbon

Ultimate Analysis (wt. \%, d.b.)

Carbon

Hydrogen

Nitrogen

Sulfur

Oxygen

HHV (Btu/lb)

Bulk Density ${ }^{\text {b }}$ (g/cc)

$\left(\mathbf{l b} / \mathbf{f t}^{3}\right)$

77.6

5.3

17.1

77.5

5.0

17.5

N.D.

N.D.

46.5

5.7

1.7

0.2

40.6

8,058

46.3

5.8

1.6

0.2

41.1

8,221

0.041

2.6

${ }^{a}$ Dry Basis

${ }^{\mathrm{b}}$ Determined from Entire Sample

${ }^{c}$ Not Determined 


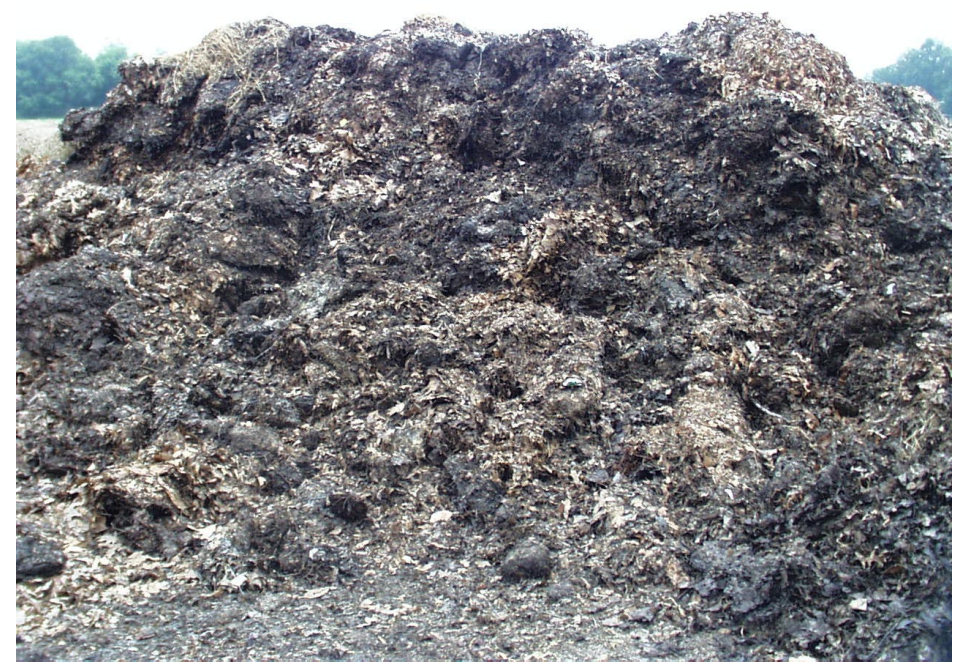

Mixed into $\mathrm{J}$ and $\mathrm{K}$

\section{Moisture}

Rep 1

$\operatorname{Rep} 2$

Rep 3

19.5

26.8

20.7

Proximate Analysis (wt.\%, d.b. $\left.{ }^{a}\right)$

Volatile Matter

Ash

Fixed Carbon

Ultimate Analysis (wt. \%, d.b.)

Carbon
Hydrogen
Nitrogen
Sulfur
Oxygen

HHV (Btu/lb)

Bulk Density $^{\mathrm{b}}$ (g/cc) $\left(\mathbf{l b} / \mathbf{f t}^{3}\right)$

${ }^{a}$ Dry Basis

${ }^{\mathrm{b}}$ Determined from Entire Sample

${ }^{\mathrm{c}}$ Not Determined

$\begin{array}{lll}71.1 & 70.3 & \text { N.D. } \\ 9.7 & 10.0 & \text { N.D. } \\ 19.2 & 19.7 & \text { N.D. }\end{array}$

$\begin{array}{lll}48.4 & 48.8 & \text { N.D. }\end{array}$

$\begin{array}{lll}5.6 & 5.6 & \text { N.D. }\end{array}$

$1.4 \quad 1.2 \quad$ N.D.

$\begin{array}{lll}0.1 & 0.1 & \text { N.D. }\end{array}$

$34.8 \quad 34.3 \quad$ N.D.

$8,000 \quad 7,975 \quad$ N.D.

0.082

5.1 


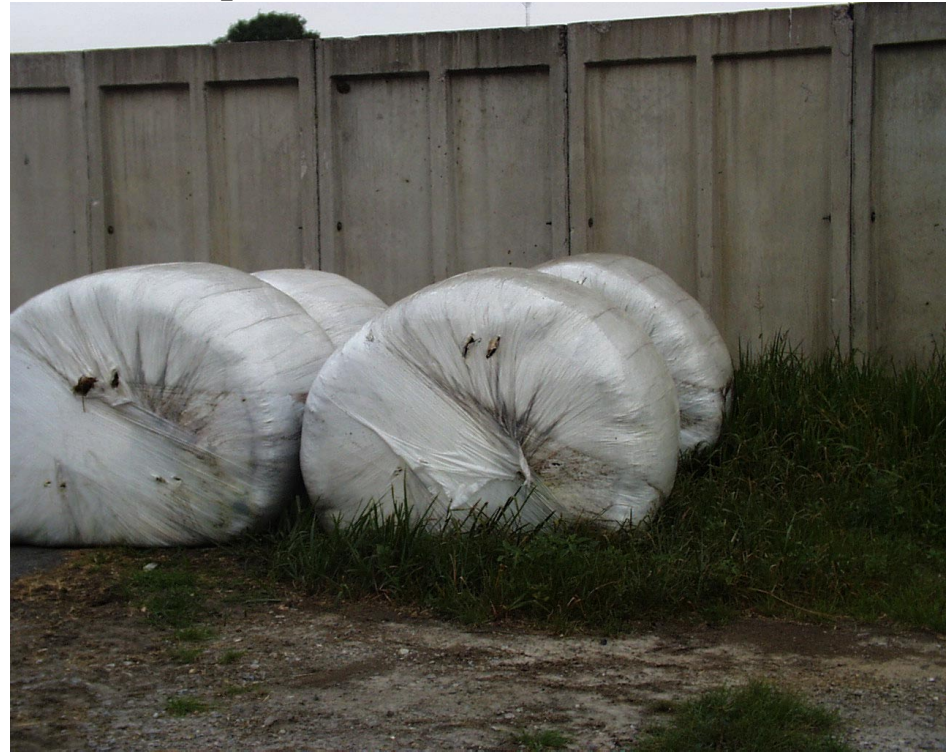

800-1,000 lb/yr

\begin{tabular}{|c|c|c|c|c|}
\hline \multicolumn{5}{|c|}{ Proximate Analysis (wt. \%, d.b. $\left.{ }^{a}\right)$} \\
\hline Volatile Matter & 92.4 & 92.5 & N.D. ${ }^{b}$ & N.D. \\
\hline Ash & 7.4 & 7.3 & N.D. & N.D. \\
\hline Fixed Carbon & 0.2 & 0.2 & N.D. & N.D \\
\hline
\end{tabular}

Ultimate Analysis (wt. \%, d.b.)

Carbon

Hydrogen

Nitrogen

Sulfur

Oxygen

HHV (Btu/lb)
66.4

11.5

0.3

0.0

14.4

18,085
71.8

12.7

0.4

0.0

7.8

20,181
73.0

11.8

0.4

0.0

N.D.

N.D.

N.D.

${ }^{a}$ Dry Basis

${ }^{\mathrm{b}}$ Not Determined 
O: Silo Bunker Cover

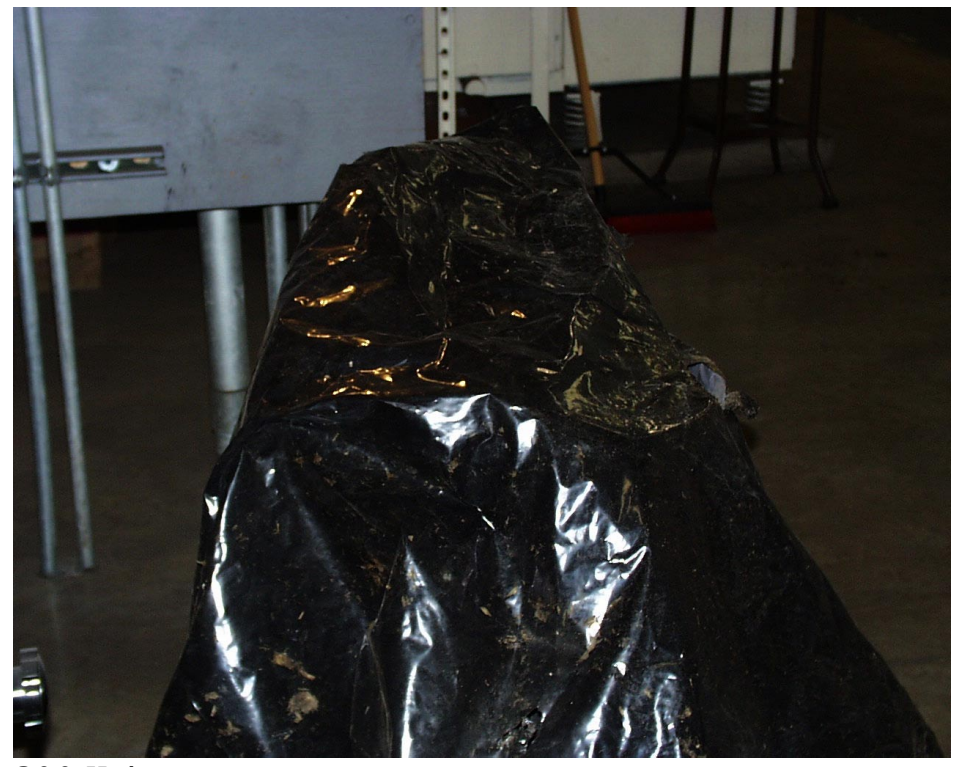

$800 \mathrm{lb} / \mathrm{yr}$

$\operatorname{Rep} 1 \quad \operatorname{Rep} 2$

Proximate Analysis (wt.\%, d.b.)

Volatile Matter

Ash

Fixed Carbon

97.3

2.6

0.0

75.5

12.8

0.2

0.2

8.7

19,202

Ultimate Analysis (wt. \%, d.b.)
HHV (Btu/lb)

Carbon

Hydrogen

Nitrogen

Oxygen

${ }^{\text {a }}$ Dry Basis

${ }^{\mathrm{b}}$ Not Determined
96.8

3.1

0.1

$\operatorname{Rep} 3 \operatorname{Rep} 4 \quad \operatorname{Rep} 5$

N.D. ${ }^{b} \quad$ N.D. $\quad$ N.D.

N.D. N.D. N.D.

N.D. N.D. N.D.

78.8

13.7

0.2

0.1

4.1

19,223
N.D. N.D.

N.D. N.D.

77.7

13.1

0.2

0.1

N.D. N.D. N.D. 
P: Misc. Manure (from covered manure barn)

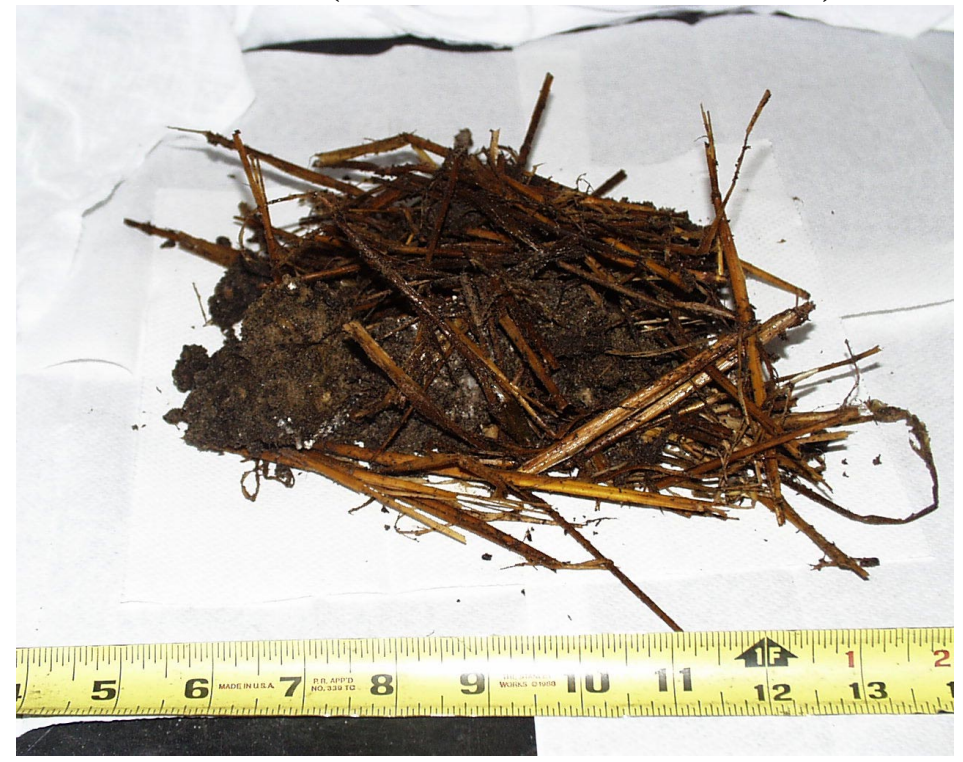

$\begin{array}{llll} & \text { Rep 1 } & \text { Rep 2 } & \text { Rep 3 } \\ \text { Moisture } & 46.1 & 55.9 & 49.6\end{array}$

Proximate Analysis (wt.\%, d.b. $\left.{ }^{a}\right)$

Volatile Matter

Ash

Fixed Carbon

Ultimate Analysis (wt. \%, d.b.)

Carbon

Hydrogen

Nitrogen

Sulfur

Oxygen

HHV (Btu/lb)

Bulk Density ${ }^{\text {b }}$ (g/cc)

$\left(\mathbf{l b} / \mathbf{f t}^{3}\right)$

19.1

2.4

1.0

0.1

3.4

3,144

0.70

43.7
22.3

73.1

4.6

20.1

2.5

1.0

0.1

3.2

2,974

N.D.

${ }^{a}$ Dry Basis

${ }^{\mathrm{b}}$ Determined from Entire Sample

${ }^{\mathrm{c}}$ Not Determined 


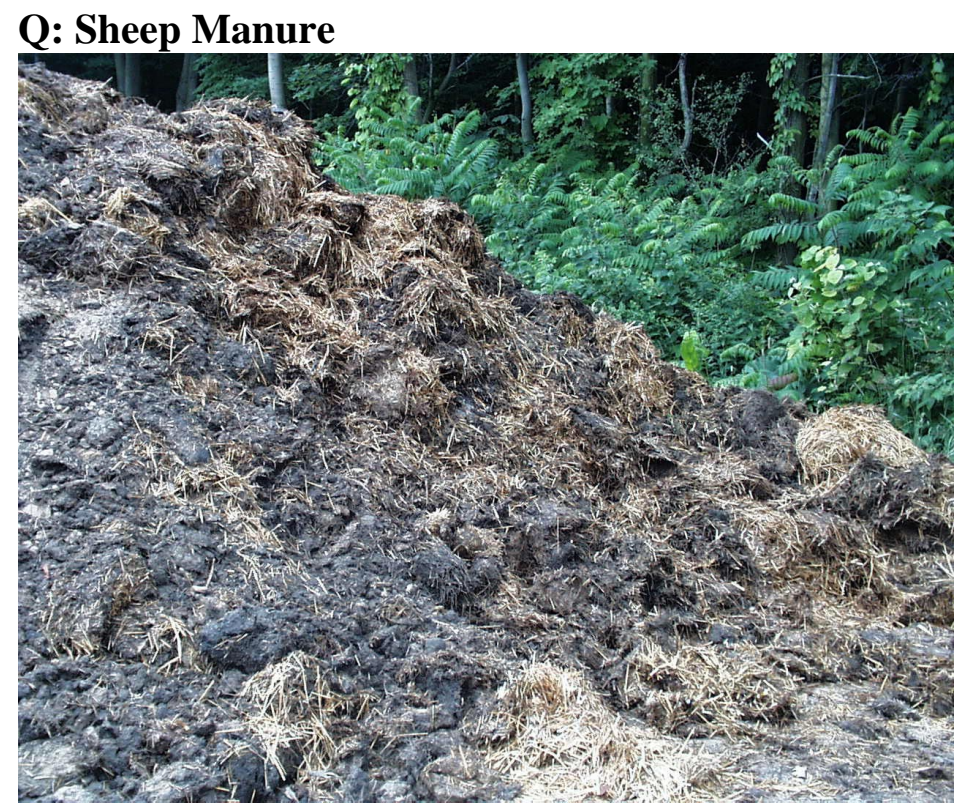

23,000 ft3/yr @ $0.37 \mathrm{~g} / \mathrm{cc}=219$ tons/yr $@ 43 \%$ moisture = $125 \mathrm{dry}$ tons $/ \mathrm{yr}$

Moisture

Proximate Analysis (wt.\%, d.b. $\left.{ }^{a}\right)$

Volatile Matter

Ash

Fixed Carbon

Ultimate Analysis (wt. \%, d.b.)

Carbon
Hydrogen
Nitrogen
Sulfur
Oxygen

HHV (Btu/lb)

Bulk Density $^{\mathrm{b}}$ (g/cc)

$\left(\mathbf{l b} / \mathbf{f t}^{3}\right)$

40.6

5.1

2.1

0.6

30.7

6,895

0.37

23.1
Rep 2

45.8

65.1

20.4

14.6

40.1

5.1

2.2

0.6

31.6

6,610

Rep 3

35.0

Rep 4

42.8

N.D.

N.D.

N.D.

N.D.

N.D.

N.D.

N.D.

N.D.

N.D.

N.D.

N.D.

\footnotetext{
${ }^{\text {a }}$ Dry Basis

${ }^{\mathrm{b}}$ Determined from Entire Sample

${ }^{c}$ Not Determined
} 


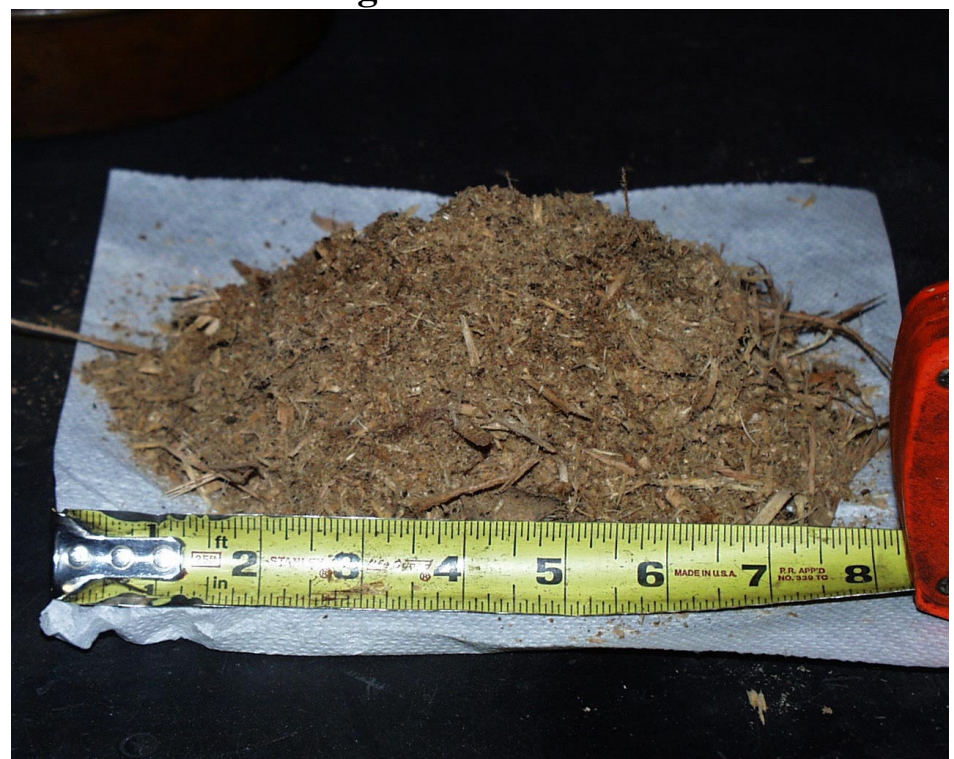

$\begin{array}{llll} & \text { Rep 1 } & \text { Rep 2 } & \text { Rep 3 } \\ \text { Moisture } & 25.4 & 28.8 & 29.0\end{array}$

Proximate Analysis (wt.\%, d.b. ${ }^{a}$ )

$\begin{array}{llll}\text { Volatile Matter } & 79.4 & 79.5 & \text { N.D. } \\ \text { Ash } & 1.6 & 1.5 & \text { N.D. } \\ \text { Fixed Carbon } & 19.0 & 19.0 & \text { N.D. }\end{array}$

Ultimate Analysis (wt. \%, d.b.)

\begin{tabular}{|c|c|c|}
\hline Carbon & 52.4 & 51.6 \\
\hline Hydrogen & 5.7 & 5.8 \\
\hline Nitrogen & 0.8 & 0.5 \\
\hline Sulfur & 0.0 & 0.0 \\
\hline Oxygen & 39.5 & 40.6 \\
\hline HHV (Btu/lb) & 8,199 & 8,069 \\
\hline Bulk Density $^{\mathrm{b}}(\mathrm{g} / \mathrm{cc})$ & 0.18 & \\
\hline
\end{tabular}

${ }^{a}$ Dry Basis

${ }^{\mathrm{b}}$ Determined from Entire Sample

${ }^{\mathrm{c}}$ Not Determined 
S: Beef Barn Manure

$55,190 \mathrm{ft} 3 / \mathrm{yr} @ 60 \%$ moisture @.6g/cc= $341 \mathrm{dry}$ tons $/ \mathrm{yr}$ 
U: Swine Waste

540,000 gal $/ y r=2,505$ tons $/ y r @ 2.2 \%$ solids = 55 dry tons/yr 
V: Reed Canary Grass

150 acres $* 4$ tons/acre/year $* 30 \%$ solids $=180 \mathrm{dry}$ tons/year

$\begin{array}{llll} & \text { Rep 1 } & \text { Rep 2 } & \text { Rep 3 } \\ \text { Moisture } & 65.2 & 74.9 & 70.1\end{array}$

